\title{
Liquid Biopsy in Melanoma: Significance in Diagnostics, Prediction and Treatment Monitoring
}

\author{
Paula Kamińska ${ }^{1}$, Karolina Buszka ${ }^{1}\left(\right.$, Maciej Zabel $^{2}$, Michał Nowicki $^{1}{ }^{\circledR}$, Catherine Alix-Panabières $^{3,4}(\mathbb{D}$ \\ and Joanna Budna-Tukan 1,* \\ 1 Department of Histology and Embryology, Poznan University of Medical Sciences, 60-781 Poznan, Poland; \\ kaminska.p19@gmail.com (P.K.); karolina.anna.buszka@gmail.com (K.B.); mnowicki@ump.edu.pl (M.N.) \\ 2 Department of Anatomy and Histology, Collegium Medicum, University of Zielona Góra, \\ 65-046 Zielona Góra, Poland; mazab@ump.edu.pl \\ 3 Laboratory of Rare Human Circulating Cells (LCCRH), University Medical Centre of Montpellier, \\ 34093 Montpellier, France; c-panabieres@chu-montpellier.fr \\ 4 CREEC/CANECEV, MIVEGEC (CREES), University of Montpellier, CNRS, IRD, 34000 Montpellier, France \\ * Correspondence: jbudna@ump.edu.pl; Tel.: +48-61854-64-28
}

check for updates

Citation: Kamińska, P.; Buszka, K.; Zabel, M.; Nowicki, M.; Alix-Panabières, C.; Budna-Tukan, J. Liquid Biopsy in Melanoma: Significance in Diagnostics, Prediction and Treatment Monitoring. Int. J. Mol. Sci. 2021, 22, 9714. https://

doi.org/10.3390/ijms22189714

Academic Editor: Andi Cani

Received: 28 July 2021

Accepted: 6 September 2021

Published: 8 September 2021

Publisher's Note: MDPI stays neutral with regard to jurisdictional claims in published maps and institutional affiliations.

Copyright: (C) 2021 by the authors. Licensee MDPI, Basel, Switzerland. This article is an open access article distributed under the terms and conditions of the Creative Commons Attribution (CC BY) license (https:/ / creativecommons.org/licenses/by/ $4.0 /)$.

\begin{abstract}
Liquid biopsy is a common term referring to circulating tumor cells and other biomarkers, such as circulating tumor DNA (ctDNA) or extracellular vesicles. Liquid biopsy presents a range of clinical advantages, such as the low invasiveness of the blood sample collection and continuous control of the tumor progression. In addition, this approach enables the mechanisms of drug resistance to be determined in various methods of cancer treatment, including immunotherapy. However, in the case of melanoma, the application of liquid biopsy in patient stratification and therapy needs further investigation. This review attempts to collect all of the relevant and recent information about circulating melanoma cells (CMCs) related to the context of malignant melanoma and immunotherapy. Furthermore, the biology of liquid biopsy analytes, including CMCs, ctDNA, mRNA and exosomes, as well as techniques for their detection and isolation, are also described. The available data support the notion that thoughtful selection of biomarkers and technologies for their detection can contribute to the development of precision medicine by increasing the efficacy of cancer diagnostics and treatment.
\end{abstract}

Keywords: circulating tumor cells (CTCs); liquid biopsy; malignant melanoma; circulating melanoma cells (CMCs); metastasis; targeted treatment; immunotherapy

\section{Introduction}

The increasing incidence of cancer remains a challenge of modern medicine [1]. Among the commonly diagnosed malignancies, melanoma, derived from epidermal improperly proliferating melanocytes, is characterized by relatively high mortality, which may be dependent on such risk factors as exposure to UV rays, high amounts of melanocytic nevi, melanoma cases in a patient's family, and specific phenotype (fair skin, eyes, sunburns easily, etc.) [2].

Conventional melanoma treatments start from surgical lesion removal and biopsy assessment [3]. As the currently used methods of cancer treatment, including chemotherapy and radiotherapy (RT), are often less effective, invasive, and cause significant complications for patient health and wellbeing, significant effort is placed on the development of more targeted approaches [4]. There are several immune therapies that have successfully been used in the treatment of malignant melanomas, solely as well as combined with other approaches, like cytotoxic T lymphocyte-associated antigen 4 (CTLA-4) inhibitor ipilimumab [5] or programmed cell death protein 1 (PD-1) inhibitors nivolumab and pembrolizumab (Figure 1) [6,7]. 


\section{T-CELL DEACTIVATION}

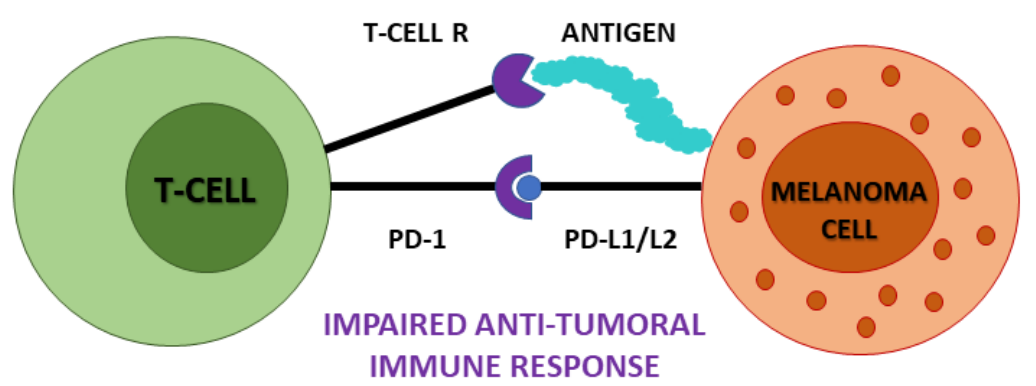

\section{T-CELL ACTIVATION}

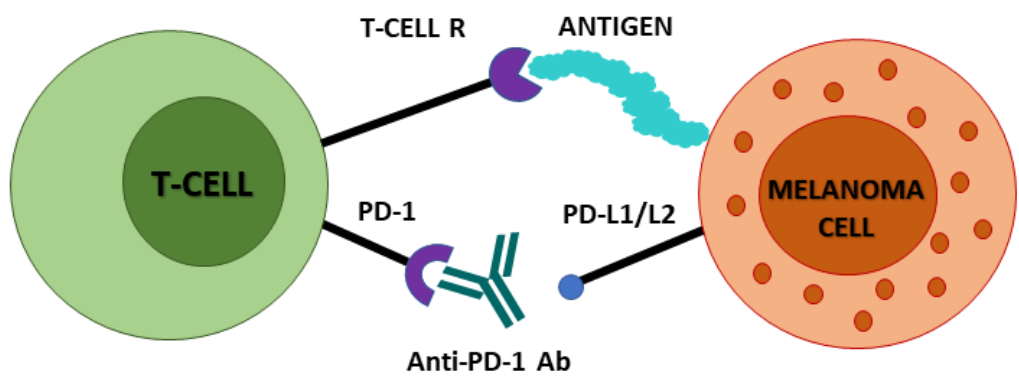

IMMUNOTHERAPY (NIVOLUMAB / PEMBROLIZUMAB)

Figure 1. Immunotherapy of PD-1-PD-L1/L2 axis blockade-mechanism of action. Anti-PD-1 monoclonal antibodies nivolumab and pembrolizumab enhance the anti-cancer response by blocking the binding of PD-1 to PD-L1/L2, thus activating T-cells to eradicate cancer cells. Abbreviations: PD-1, programmed cell death 1; PD-L1/L2, programmed cell death ligand 1/2; T-cell R, T-cell receptor; $\mathrm{Ab}$, antibody.

The recent statistics for this disease show a promising trend-mortality is steadily declining, presumably as a result of the approval of new therapeutic methods, especially immunotherapy. Nevertheless, the appearance of new cases is still relatively high [8]. A standard diagnostic procedure involves a panel of tumor markers and a biopsy of the lesion. However, due to their invasiveness, traditional tumor biopsies are not suitable for continuous disease monitoring [9]. Research aimed at overcoming this obstacle led to the introduction of so-called liquid biopsies, minimally invasive and cost-effective diagnostic methods with a high level of sensitivity [10-13]. The term, first used by Pantel and Alix-Panabières [14,15], refers to a blood test that provides comparable or even more specific information than the classic tissue biopsy. These could include the concentration of proteins, or the presence and expression of tumor markers, with the latter mainly consisting of circulating tumor cells (CTCs) and their products [16]. Many current reports indicate CTCs, as well as circulating tumor DNA (ctDNA), circulating cell-free mRNA, and exosomes as promising biomarkers for diagnosis, control of disease progression, or evaluation of treatment effectiveness in many types of cancers (Figure 2) $[11,17,18]$.

Differences in disease outcome, prognosis, and the availability of effective targeted therapies require tools for better stratification, selection of the optimal time to start the therapy, and drug resistance monitoring. The diversity of melanoma in terms of surface marker expression makes reliable detection a challenge and thus inspires the use of different detection methods [19]. 


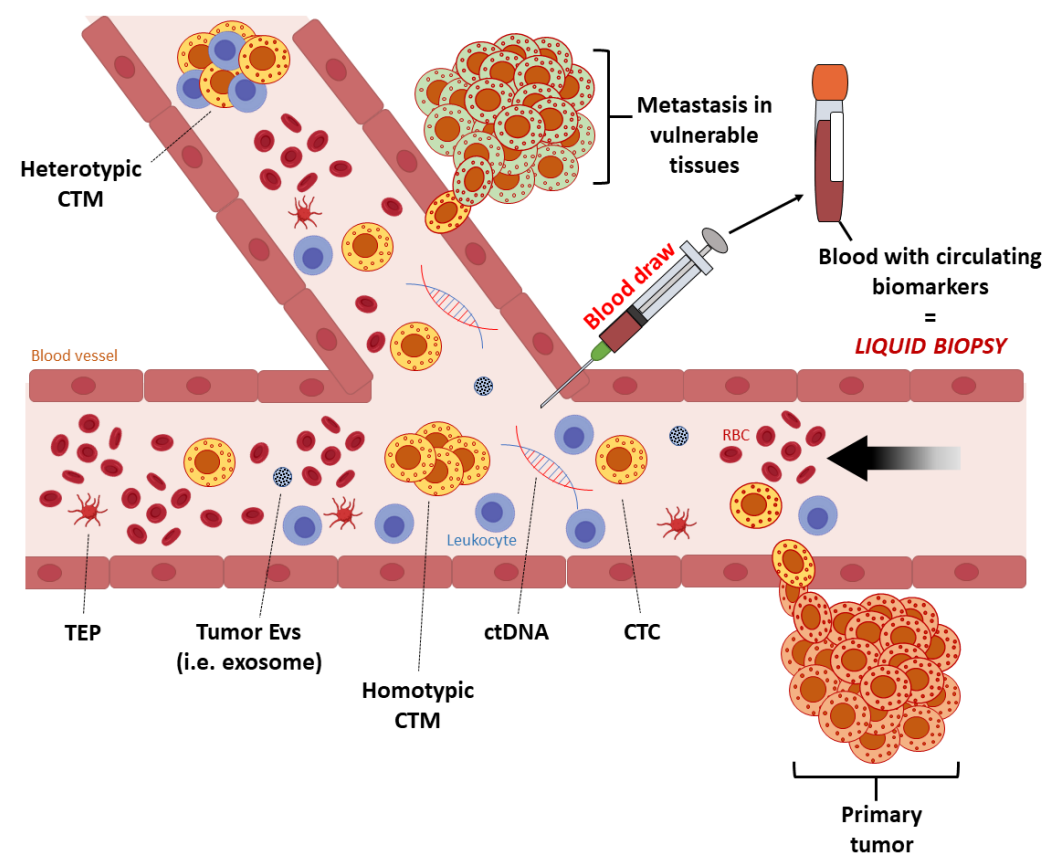

Figure 2. A schematic of liquid biopsy in a patient with a solid tumor. Tumor cells circulate in blood, with those that are more aggressive (metastasis-initiator cells) settling in targeted distant organs and initiating metastasis. Blood collected from cancer patients contains circulating tumor cells (CTCs), clusters or circulating tumor microemboli (CTM), proteins, circulating cell-free tumor DNA (ctDNA), extracellular vesicles (EVs), such as exosomes, and tumor educated platelets (TEPs). These complementary circulating biomarkers can be detected and provide real-time information on tumor progression, prognosis, and treatment response. Abbreviations: CTCs, circulating tumor cells; ctDNA, circulating tumor DNA; CTM, circulating tumor microemboli.

\section{Liquid Biopsy in Melanoma}

2.1. Circulating Melanoma Cells (CMCs)

CTCs in melanoma, known as circulating melanoma cells (CMCs), were described in the early 1990s [20]. Like all circulating tumor cells, CMCs descend from the primary tumor [21]. For an invasion to occur, cancer cells must change their nature periodically to suit the current environment. Therefore, CTCs undergo reversible phenotypic changes enabling epithelial-mesenchymal transition (EMT) [22]. During this process, changes in the cytoskeleton occur, together with a loss of adhesive proteins, which increases the mobility of cancer cells [23]. This enables their transport from the primary location to other, distant and susceptible tissues, as well as the formation of micro- and/or macro-metastases. These processes suggest a large heterogeneity of CMCs [24], making it necessary to constantly search for new and improved methods of their use in melanoma diagnostics. Another disadvantage is the relatively low number of CMCs in peripheral blood, with 1-3 CMCs corresponding to 5 billion blood cells [25]. Thus, an enrichment stage increasing the concentration is highly recommended for an optimized CMC detection [18].

In contrast to other cancer types, which frequently establish CTMs (circulating tumor microemboli) in metastatic stages, CMCs occur mostly individually in the bloodstream of patients with melanoma [26]. However, Long et al. confirmed the existence of CTMs in metastatic melanoma patients. The presence of such clusters reflects the increased metastatic potential and higher invasiveness of cells, affecting the overall survival. This occurrence could result from the heterogeneous phenotype of cells enclosed in CTMs [27], as well their higher resistance to apoptosis [28].

CMCs express a variety of surface antigens used in various isolation and detection techniques, including melanoma cell markers, e.g., MCAM (melanoma cell adhesion molecule, MCAM/MUC18/CD146) [25], MART-1 (melanoma antigen recognized by T cells 
1/Melan-A) [29], MAGE-A3 (melanoma antigen A3), PAX3 (paired box 3), HMW-MAA (human high-molecular weight melanoma-associated antigen) [30] and GM2/GD2 (gangliosides) [31]. Importantly, none of the mentioned antigens' expression is restricted to melanoma cells. Some of them can be found on benign melanocytes and nevi (MCAM, HMW-MAA, MART-1), spermatocytes and other cancer cells (MAGE-3), and endothelial cells (MCAM), while others on normal tissues (PAX3, HMW-MAA) [32]. Thus, antigenbased detection technologies carry the risk of non-specific staining, and results need to be analyzed in relation to clinical data.

Another important melanoma-specific marker is the S100 protein. The S100 protein family consists of 21 structurally similar but functionally different proteins. Their abnormal expression is characteristic for melanoma, with different types of this disease characterized by a different set of expressed proteins, stimulating processes associated with cancer progression [33]. The presence of those proteins confirms the viability of cancer cells that participate in the malignant invasion, making S100 proteins useful in disease monitoring and prognosis [20].

\subsection{Circulating Tumor DNA (ctDNA)}

Apart from CMCs, the "liquid biopsy" also includes other blood-based biomarkers. Among them, circulating cell-free DNA (cfDNA), first described by Mandel and Metais in 1948 [34], was found to be a good source of information about specific mutations and gene alterations. This double-stranded DNA fragment forms a protein complex, with its length ranging from 18 to 10,000 bp [35]. Its presence results from physiological cell functions, such as secretion, apoptosis, or necrosis [36], and can be found in different types of body fluids, including plasma [34]. Nevertheless, it was discovered that cancer patients exhibit higher cfDNA blood levels than healthy controls $[18,37]$. Hence, cancer-derived cfDNA, referred to as circulating tumor DNA (ctDNA), has attracted significant research attention. Comparing to cfDNA, ctDNA is shorter, around 134-144 bp [38], and usually fragmented because of the presence of nucleosomal single, double, or triple complexes. As blood collection is minimally invasive, ctDNA samples could be collected to examine changes in their quantity and composition overtime, being a useful tool for cancer detection and monitoring [37]. Although ctDNA is quickly degraded by nucleases, with a half-life of less than $2 \mathrm{~h} \mathrm{[39],} \mathrm{its} \mathrm{amount} \mathrm{was} \mathrm{shown} \mathrm{to} \mathrm{correlate} \mathrm{with} \mathrm{the} \mathrm{stage} \mathrm{of} \mathrm{the} \mathrm{disease,} \mathrm{size} \mathrm{of} \mathrm{the}$ tumor, and the presence of metastases, also in melanoma [40,41].

Since cutaneous melanoma is regarded as a tumor of high tumor mutation burden (TMB) [42], detection of tumor-specific changes, such as variations in DNA integrity, chromosomal rearrangements, or mutations in oncogenes and tumor suppressor genes [35], allows for early detection of the primary disease, adjustment of targeted therapy, treatment progress monitoring, estimation of recurrence risk, and detection of treatment-resistance mutations [43-46].

Genes subjected to somatic mutations testing include BRAF, CDK4, GNAQ, JAK2, KRAS, MAP2K1, NF1, NRAS, and STAT1 [40], with most commonly detected mutations affecting BRAF (V600E/K/R, L597R/S), NRAS (Q61K/L/R, G12D), and KIT (L576P). Among them, the most common is the BRAF oncogenic driver V600 mutation, as it is found in $40-50 \%$ of cutaneous melanomas [47].

Since hypermethylation at the promoter region of tumor suppressor genes, e.g., RARB2, TFPI2, RASSF1A, MGMT, and PTEN, helped to distinguish melanoma patients from healthy individuals [48], epigenetic changes in cfDNA may also serve as diagnostic markers in melanoma [49].

Thus, ctDNA is a promising biomarker for the detection of crucial mutations and epigenetic changes, helping to manage patients with melanoma in diagnostic and therapeutic aspects. Defining the profile of genetic alterations in reference to neoplasm progression is of the greatest importance in terms of patient stratification improvement [50]. 


\subsection{Melanoma-Derived Exosomes}

Melanoma can modulate its microenvironment through various kinds of factors, promoting its growth and formation of metastasis. Among direct cellular interactions, secretion of signaling factors (cytokines, chemokines, growth factors) and shedding of extracellular vesicles (EVs), are among the most promising sources of cancer information [51]. EVs are commonly divided into shedding vesicles (SVs) and exosomes, depending on the subcellular mechanism of formation and release [52]. Exosomes are nano-sized vesicles of about $100 \mathrm{~nm}$, surrounded by a lipid bilayer [51,53], released into the external microenvironment through the fusion of subcellular multivesicular bodies with the plasma membrane [54]. Although they are found in large quantities in most body fluids, e.g., blood, urine, and breast milk [55,56], exosomes are also involved in vascular leakage in pre-metastatic sites, which plays an important role in the formation of the pre-metastatic niche [57].

The ability of exosomes to participate in intercellular communication, as they partake in the transfer of proteins, RNA, or lipids, indicates their potential involvement in mechanisms of cancer origin $[53,58,59]$. The evidence that melanoma exosomes can actively communicate with nearby melanocytes comes from the study of Xiao et al., in which exosomes derived from an A375 melanoma cell line and primary normal human epidermal melanocytes (NHEM cell line) were marked with a red and green dye, respectively. During the time of observation, the red-labeled exosomes merged with the membranes of primary green-labeled melanocytes, with a change of color to orange observed [60].

Their molecular cargo, consisting of unique mRNA, miRNA, and proteins, was found both in melanoma cell lines [61] and blood of advanced-stage melanoma patients [62].

A connection has been reported between exosomes and drug resistance in many types of cancers, including melanoma [63,64]. PDGFR $\beta$, belonging to the group of tyrosine kinase receptors, is overexpressed in melanoma and was identified as a drug resistance factor. Exosomes were shown to transfer PDGFR $\beta$ to melanoma cells, activating the phosphatidylinositol-3-kinase (PI3K-AKT) signaling pathway, involved in the growth and survival of cancer cells, consequently lowering the sensitivity to BRAF inhibitors [65].

Since exosomes carry a molecular "fingerprint" of the cell of origin, they could deliver invaluable information about the cancer status, making them prospective biomarkers for melanoma diagnosis or prognosis [66].

\section{Technologies for Liquid Biopsy in Melanoma}

\subsection{CMC Enrichment and Detection}

Most commonly, the first step of CMC detection considers their enrichment, significantly increasing cell concentration in the sample and removing unnecessary cells through, e.g., sample centrifugation and positive or negative selection [18,67]. Then, isolation and characterization can be performed based on the physical or biological features of the cells [18]. Physical methods depend on size, density, deformability, and electric charges, whereas biological methods are based on protein marker expression [68].

Physical methods might be useful regardless of population heterogeneity [68], as was proven by Aya-Bonilla et al., who found various CMC subpopulations in metastatic melanoma patients [69]. The more advanced alternative is based on isolation by size of epithelial tumor cells (ISET), being also suitable for cells of non-epithelial origin like CMCs. This single step size-based enrichment ensures the integrity of isolated cells, enabling their further testing using qRT-PCR or immuno-cytochemistry. The essential advantage of ISET is its detection sensitivity of $1 \mathrm{CMC}$ per $1 \mathrm{~mL}$ of blood [26]. Another marker-independent

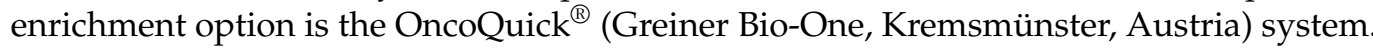
This methodology uses the concept of gradient centrifugation with the use of a porous membrane device. The initial cell fraction is enriched $400-500$ times, which translates to high CMC yields, and assessed by increased RNA levels compared to the control group.

In turn, only targeting melanoma-specific markers leads to selective isolation and reliable analysis of CMCs [70]. For this purpose, the positive immunomagnetic approach is commonly used. The principle is based on the application of antibodies labeled with 
magnetic beads against antigens of interest, enabling the extraction of CMCs in the magnetic field. Among targeted proteins, HMW-MAA [71], MCAM, ABCB5 (ATP-Binding cassette subfamily B member 5), CD271 [70], CD133, and nestin [72] are often selected, often in combination to deal with the problem of heterogeneity. Several technologies based on the abovementioned principle have been developed so far, e.g., EasySep ${ }^{\circledR}$ (Stemcell Technologies, Vancouver, BC, Canada) [72], MACS ${ }^{\circledR}$ separator (Miltenyi Biotec, Bergisch Gladbach, Germany) [73], Dynabeads ${ }^{\circledR}$ Antibody Coupling Kit (Invitrogen, Waltham, MA, USA) [70], and Dynabeads ${ }^{\circledR}$ CELLection Pan Mouse IgG Kit (Invitrogen) [74]. Although very selective, it has to be noted that positive isolation can omit cells not expressing certain antigens, thus some CMC subpopulations.

On the contrary, immunomagnetic negative selection depletes all leukocytes through CD45 targeting or endothelial cells through CD34 targeting [75,76], leaving remaining $\mathrm{CMCs}$ intact and suitable for phenotyping and molecular analysis. However, the risk of losing CMCs with the CD45 population exists [74], showing that neither approach is perfect. Nevertheless, the ability to isolate even relatively small subsets of CMCs was shown to be clinically relevant [70].

As far as detection is concerned, widely used strategies based on the use of EpCAM (epithelial cell adhesion molecule) and other epithelial markers are not useful in this context, as their expression does not occur in melanoma cells [25]. Instead, CMC isolation methods based on an immunomagnetic approach utilize specific melanoma markers. CellSearch ${ }^{\circledR}$ is an example of such methods, designed for isolation of CMCs based on an immunomagnetic capture of cells expressing MCAM (CD146) on their surface from whole blood samples (Figure 3) [24].

\section{CMC ENRICHMENT Positive selection}

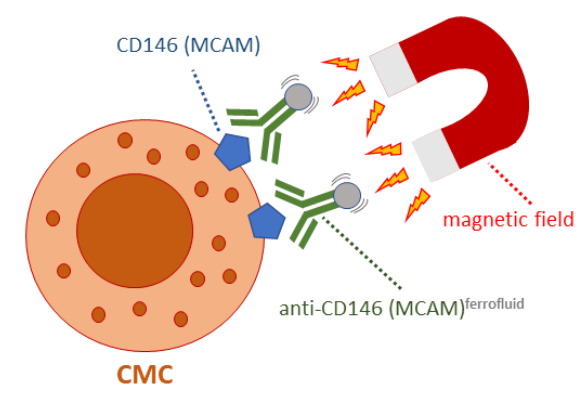

\section{CMC DETECTION}

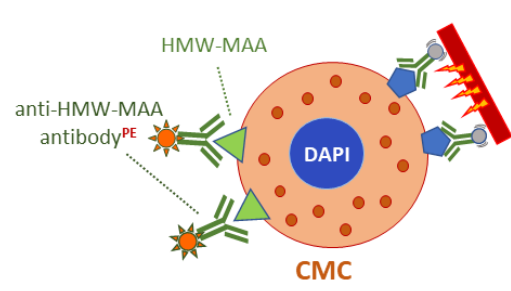

LEUKOCYTE AND ENDOTHELIAL CELL

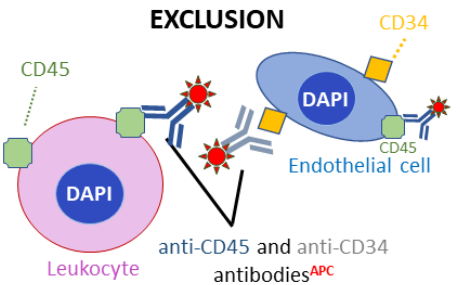

$$
\begin{aligned}
& \text { CMC identification: } \\
& \text { CD146 } \\
& \mathrm{HMW}^{(+)} \mathrm{MAA}^{(+)} \\
& \mathrm{DAPI}^{(+)} \\
& \mathrm{CD}^{(-)} 5^{(-)} \text {CD } 34^{(-)}
\end{aligned}
$$

Figure 3. CellSearch ${ }^{\circledR}$ strategy to enrich and detect CMCs in patients with a melanoma. The positive CMC enrichment is based on the expression of CD146 by melanoma cells. Subsequently, CMC detection is based on the expression of the high molecular weight melanoma-associated antigen, as well as the presence of a nucleus (visualized using DAPI). The exclusion markers are (i) CD45, specific for leukocytes and some endothelial cells and (ii) CD34, expressed by endothelial cells. As endothelial cells also express CD146, CD34 is important to consider to discriminate these cells from CMCs that are CD34 ${ }^{(-)}$. Abbreviation: MCAM, melanoma cell adhesion molecule; HMW-MAA, high molecular weight; PE, phycoerythrin; APC, allophycocyanin. 
Another group of methods contains modifications of flow cytometry (FCM), such as immunomagnetic cell sorting [73], fluorescent-activated cell sorting (FACS) [72,77], or photoacoustic FCM. Goldschmidt and Viator employed the latter approach for CMC capture, detection, and isolation. The method allowed for the detection of individual melanoma cells, which were highly viable and therefore could be successfully subjected to further analyses [78].

The viability of $\mathrm{CMCs}$ is a significant biological feature, corresponding to the extent of metastatic potential used in prognosis estimation [18]. Epithelial ImmunoSPOT (EPISPOT) assay allows for the detection of viable cells (also of non-epithelial origin) due to their ability to produce proteins, in case of CMCs, particularly S100. Antibodies are oriented against protein products, each being a "fingerprint" of a living cell. This is a major advantage over CellSearch ${ }^{\circledR}$, which detects both viable and dead cells, potentially making EPISPOT a better method for metastasis progression prediction [79].

Lastly, RT-PCR methods are frequently used for indirect detection of CMCs, through amplification of mRNA (e.g., tyrosinase, Melan-A, MART-1, PAX) extracted from blood [68]. Tyrosinase expression is typical for melanoma cells and melanocytes, with neither of them found in healthy patients' blood $[80,81]$. Research by Smith et al. indicated high sensitivity of this method for the detection of cancer cells [82], which was confirmed in later studies [80]. Importantly, it was found that combining various markers in a socalled multimarker RT-PCR increases the sensitivity of this approach and helps to mitigate the effects of CMC heterogeneity, giving RT-PCR methods an advantage over selective immunomagnetic cell capturing.

In turn, DNA sequencing gives the possibility to detect genetic changes characteristic for melanoma. Certain abnormalities occur solely in cancer cells and might therefore be considered as tumor markers, with their tracking enabled via PCR or next-generation sequencing (NGS) methods $[83,84]$. Thus, melanoma type-specific mutations are crucial for detection technique accuracy. The most common mutations in the CSD type are associated with NF1 (neurofibromin 1), NRAS, BRAF, or KIT (KIT Proto-Oncogene, Receptor Tyrosine Kinase) genes [85]. In turn, $B R A F$ mutations are the dominating genetic causative factor in superficial spreading melanoma (SSM) [85], whereas for ALM, typical mutations can be found in the BRAF, NRAS, KIT, and NF1 genes [86].

\section{2. ctDNA Detection}

The amount of ctDNA present in the circulation of melanoma patients at the onset of the disease is small and accompanied by DNA from non-cancerous cells, thus proper identification of disease in its early stage is often hampered [87]. To isolate and analyze ctDNA from plasma samples, sensitive molecular techniques are used, often preceded by detection of primary tumor-specific mutations $[88,89]$.

Following the tumor characterization and pre-identification of gene targets, isolated ctDNA can be subjected to PCR-based methods, which can be divided into targeted and nontargeted sequencing. The former is highly sensitive and predominantly include droplet digital polymerase chain reaction (ddPCR) and bead-emulsion-amplification-magnetics (BEAMing) technology, both based on quantification following DNA amplification in water-oil droplets, with comparable and sufficient reproducibility [90]. Most studies applied ddPCR, as it enables detection of $B R A F$ and $N R A S$ gene mutations, allowing patient response to immunotherapy to be evaluated, as well as recurrence and pseudo-progression to be detected [91]. Studies of Wong et al. [92], Váraljai et al. [93], McEvoy et al. [94], and Forthun et al. [83] confirmed ddPCR validity through quantification of TERT promoter and $B R A F / N R A S$ mutations. The mutational profile, together with ctDNA levels, was associated with disease progression and is useful for monitoring bevacizumab treatment response. The safe-sequencing system (Safe-SeqS), cancer personalized profiling via deep sequencing (CAPP-Seq), and tagged-amplicon deep sequencing (TAmSeq) are other examples of targeted techniques [95]. 
In turn, next-generation sequencing (NGS) is carried out via whole-genome sequencing (WGS) whole-exome sequencing (WES), whole transcriptome shotgun sequencing (WTSS), targeted (TS) or candidate gene sequencing (CGS). While these methods enable a complex analysis of genetic changes in ctDNA, their lower sensitivity requires a higher concentration of ctDNA, which usually makes them unsuitable for patients without metastases $[96,97]$.

Therefore, currently developed approaches are focused on the successful detection of mutations and epigenetic changes in ctDNA of low concentration. In melanoma, widely distributed mutations in BRAF and NRAS genes make most of the technologies suitable for analysis. However, in the case of patients harboring BRAF and NRAS wild-types, analysis is far more complicated. The solution for this problem may be newly introduced approaches based on MALDI-TOF mass spectrometry [89] or a combination of surface-enhanced Raman spectroscopy with PCR [98]. However, their utility is yet to be confirmed.

Gorges et al. presented the advantages of combined analysis of CMCs and cfDNA, which provides a significant amount of information about tumor profile from a singular blood sample [99]. Similarly, in the research of Salvianti et al., CMCs, as well as cfDNA, were used to detect mutated $B R A F(V 600 E)$ via qRT-PCR and were validated using ICE COLD PCR with Sanger-sequencing. The authors propose the combined analysis since cfDNA is not tumor-specific, and CMCs might provide useful information about tumor heterogeneity [100].

\subsection{Exosome Isolation}

Although the distinction between tumoral and physiological exosomes is hardly impossible, it is believed that cancer patients present higher content of exosomes, which could serve as a reliable biomarker for tumor management [101]. Exosome analysis differs from the abovementioned techniques, as obtaining exosomes carrying particular content depends on the isolation method used [102].

These generally involve a series of ultracentrifugation steps of different speeds, lasting several hours, to exclude cells, their residues, and, most importantly, to separate exosomes from other types of EVs. This method provides high recovery, along with improved specificity in comparison to single speed non-differential ultracentrifugation [103]. Tubes in more advanced ultracentrifugation are additionally equipped with a density gradient enabling separation of even slightly different EVs based on their density [104]. Combining both methodologies allows cost-effective and efficient purification of a satisfactory number of exosomes to be used for further studies, focusing on their cargo, e.g., proteins and miRNAs [54]. To improve enrichment via ultracentrifugation, it can be preceded by a filtration step, using a $0.22 \mu \mathrm{m}$ filter, removing cell debris, protein aggregates, and lipoproteins [105].

The size of exosomes is the feature used for their enrichment via ultrafiltration or size exclusion chromatography $[106,107]$. The procedure relies on the application of Sepharosefilled columns of certain porosity, allowing separation of exosomes from other EVs. Although they are characterized by intermediate recovery, possibly resulting in contamination with other EVs types and proteins [104], the use of both methods for more effective isolation can be beneficial. As an example, Shu et al. combined ultrafiltration and size exclusion chromatography, which allowed more exosomes to be isolated than in any of the individual approaches [102].

Purification effectiveness is usually evaluated by the presence of markers specific for endosomal plasma membrane and cytoplasmic components enclosed within vesicles, as well as a simultaneous absence of contaminants like albumin and A1/2 and B apolipoproteins [104].

Yet another isolation method is based on immunoaffinity, directly retrieving exosomes expressing CD9, CD63, or CD81 on their surface. Reagents for such isolation are currently available as commercial kits using columns or microbeads, e.g., ExoQuick ${ }^{\circledR}$ and ExoTEST $^{\circledR}$. Similarly, in this method, the obtained exosomes can be subjected to further research. 
However, its disadvantages include the small test sample volume and that its effectiveness is dependent on the presence of specific markers [54]. The latter can significantly limit the utility of this approach, as EVs were found to be heterogeneous, with particular surface markers shared among various EVs subtypes [108]. This especially undermines the use of a single marker, e.g., CD63, which is also expressed on EVs secreted in some tumors [109]. Thus, multi-marker solutions are superior to single marker targeting. Logozzi et al. utilized an ExoTEST ${ }^{\circledR}$ assay for detection and quantification of exosomes expressing CD63, Rab-5b, and caveolin-1. While a higher amount of CD63-positive and caveolin-1-positive exosomes were found in melanoma patients, detection based on caveolin-1-positive exosomes was more sensitive than that targeting CD63 [110].

In the context of melanoma, the team of Sharma et al. used an immunoaffinity approach for the capture of melanoma-derived exosomes from plasma, based on a monoclonal antibody highly specific for the CSPG4 epitope expressed by melanoma cells. Only melanoma-derived exosomes presented its expression, making them useful biomarkers of melanoma progression [111].

\section{Clinical Relevance of Liquid Biopsy in Melanoma \\ 4.1. Melanoma Detection and Prognosis}

The available data suggest that enumeration of CMCs is a suitable tool for melanoma detection, allowing evaluation of its stage and prognosis. Unfortunately, the results are not consistent since various approaches are implemented by different study groups to overcome the problems of CMC rarity and heterogeneity.

Nevertheless, a few studies have already been performed proving that presence of CMCs is clinically relevant and carries prognostic value. Freeman et al., using immunomagnetic enrichment and combination of MCAM, melanoma-associated chondroitin sulfate proteoglycan (MCSP), ABCB5 and CD271 markers, showed that significantly more patients harbored CMCs in comparison to healthy individuals. However, single CMCs were also found in the control group. More importantly, there was a difference in CMC counts between metastatic and non-metastatic patients, making CMC enumeration possibly helpful for determining disease progression [70]. Studies by Ulmer et al. also showed that the number of CMCs was associated with occurrence, aggressiveness, and stage of the disease. The relation likewise applied to the overall survival (OS) of metastatic patients [112]. Similarly, differences in length of OS were observed between groups of patients harboring at least two CMCs and less than two CMCs per tested blood sample, being significantly shorter in the first case (2.0 vs. 12.1 months, respectively) [76].

Detection of tyrosinase (TYR) mRNA was found to be highly sensitive for identification of circulating melanoma cancer cells [80], with a study conducted by Stevens et al. reporting that the presence of TYR mRNA in the blood correlated with disease stage in melanoma [81]. Furthermore, a combined analysis with Breslow's thickness and disease stage was determined as a prognostic approach for estimating disease-free survival (DFS) [113].

Analysis of multiple melanoma-associated mRNA transcripts (MART-1, GalNAc-T, $P A X-3$, and MAGE-A3), performed by Koyanagi et al., revealed a significant correlation between the number of positive markers and I-IV stage of the disease [114]. In turn, the outcome of a comprehensive search conducted by Khoja et al., aiming at analysis of already performed studies, was less conclusive. The results showed that CMC detection performed on I-III stage melanoma patients, based on the analysis of melanocytic transcripts (TYR, MELAN-A/MART-1, MAGE-3, PMEL) in the blood or PBMC fraction, presented great variation, with CMC outcome ranging from $13.8 \%$ [115] to $80.5 \%$ [116], thus not always being prognostically significant. Among them, the stage III patient group showed the greatest clinical utility, confirming the relation between CMC number and factors like risk of developing distant metastasis, as well as shorter DFS and OS [117]. A similar observation was made with pooled stage I-IV patients, both using melanocytic transcripts analysis and CellSearch $^{\circledR}[75,118,119]$. Additionally, Hoshimoto et al. showed that the presence of more 
than one mRNA marker before and during the course of the treatment negatively influenced DFS and OS [118]. Interestingly, in ocular melanoma, sharing the same melanocytic markers and analyzed using the same platforms as cutaneous melanoma, five studies presented concordant results, indicating that CMCs are also prognostic factors in this type of disease [120-124]. PCR-based methods also proved to be helpful for identifying groups of patients with a higher risk of recurrence after lymph node removal due to the presence of metastases. The expression of mRNA markers (TYR and MART-1/Melan-A) before the clinical onset of the disease proved to be useful for future relapse prognosis, with $83 \%$ sensitivity and $41 \%$ specificity [125].

When applying multiparametric flow cytometry, it was also presented that CMCs detected based on the limited expression of MCAM, MCSP, ABCB5, receptor activator of NFKB (RANK), and CD271 markers were far more abundant in melanoma, especially in latestage patients in comparison to healthy controls. This observation did not apply to earlystage patients exclusively, where marker co-expression was extremely limited. Interestingly, a comparison of CMCs with corresponding tumor tissue revealed that ABCB5 and RANK expression is more attributed to CMCs than the tumor itself. This signifies that melanomainitiating cells are likely preferentially released to blood circulation, causing metastatic spread. Moreover, the higher number of RANK-positive cells reflected shorter progressionfree survival (PFS) [126]. These findings were confirmed by another study using the same detection method, which found significantly increased expression of metastasis-associated RANK in CMCs from melanoma stage IV vs. stage I patients, demonstrating that increased RANK expression can be a marker of metastatic melanoma [127].

Flow cytometry was also used for comparative analysis of CMCs positive for nestin (NES) and CD133, molecular markers of melanoma-initiating cells, with metastatic tissue samples. The results showed a high concordance of marker expression profile between the former and the latter. Additionally, a prevalence of NES-positive CMCs was associated with tumor burden and number of metastases, also being related to shorter OS [72].

Data obtained in the course of a meta-analysis of 53 studies focused on the abovementioned immunomagnetic cell enrichment, PCR-based methods, and a cytometric approach revealed that the prevalence of CMCs correlated with disease stage in melanoma. However, various limitations of the study design largely undermine the favorable results of this analysis [128].

Similar results were obtained by other study groups using ${ }^{\mathrm{HB}}$ CTC-Chip capture [129] and a filtration method [130], also showing that CMCs can be correlated with advanced disease stage.

All this taken together indicates that CMCs are a potentially reliable factor for disease diagnosis and relapse prognosis. However, the extremely high heterogeneity of this population and multiple testing platforms of different sensitivity and specificity can lead to both false-positive and false-negative results, diminishing their clinical relevance.

Since studies of Aya-Bonilla et al. showed concordance between the dynamics of $\mathrm{CMC}$ scores and changes in ctDNA, it is suggested that the latter can serve as a promising biomarker for melanoma monitoring [69]. While a higher concentration of ctDNA is often detected in the plasma of patients with progressive disease, destruction of cancer cells during initiation of therapy may also lead to elevated ctDNA levels [131]. Remarkably, even patients with a low tumor load prior to therapy who progressed at first follow-up already presented higher ctDNA levels at the baseline. Furthermore, an increase in ctDNA concentration at first follow-up negatively influenced the length of OS, indicating that evaluation of ctDNA levels in treatment-naïve patients can be a prognostic factor associated with OS [40].

Apart from total ctDNA concentration, specific mutation analysis in ctDNA can also be performed. Since $B R A F$ mutations are present in the majority of cutaneous melanoma patients, ctDNA analysis can be of great value in their context, representing a reliable alternative to the tissue biopsy [132]. It was found that accordance between tissue and plasma $B R A F(V 600 E)$ ranged from $75 \%$ [133] to $84 \%$ [134], making its quantification a 
reliable biomarker in melanoma. Furthermore, an abundance of $B R A F(V 600 E)$ ctDNA in treatment-naïve patients was related to tumor burden, with lower concentration reflecting longer OS and PFS compared to higher concentration (27.7 vs. 8.6 months and 9 vs. 3 months, respectively) [134].

The commonness of brain metastases development in the course of melanoma emphasizes the need for finding a sensitive tool, reflecting their status, and predicting response to therapy. A study by Lee et al. evaluated ctDNA in relation to active brain metastases treated with PD-1 inhibitors-pembrolizumab or nivolumab. Prior to the treatment, ctDNA was not detected in patients with intracranial metastases and thus was not associated with their presence. Conversely, ctDNA concentration reflected the volume of extracranial disease. Furthermore, its appearance preceded or coincided with the extracranial metastatic spread [135].

Finally, ctDNA can be applied for non-typical melanoma mutation detection (wildtype patients, constituting ca. $20 \%$ of all melanoma cases) [136] and tumor-specific gene methylation detection and be used for early diagnosis of melanoma [137]. Several study results showed that the presence of hypermethylation in the promoter region of PTEN, TFPI2, RARB2, MGMT, and RASSF1A genes in ctDNA enabled differentiation of melanoma patients from healthy individuals [138-140], with elevated levels of methylated RASSF1A ctDNA more attributed to metastatic cases compared to early-stage melanoma [140]. Moreover, the RASSF1A hypermethylation, most common in melanoma [140,141], was predictive for shortened OS [140] and poor response to biochemotherapy [141,142]. Similarly, hypermethylation in the AIM1 gene and hypomethylation of the LINE-1 gene detected in ctDNA were related to adverse prognosis in melanoma [143]. This piece of information suggests that although DNA methylation is not restricted to tumor cells, it is attributed predominantly to cancer-related pathways and thus may deliver vital diagnostic and predictive data [44].

Despite the abovementioned findings, ctDNA is a sensitive tool, preferentially used to monitor response to treatment instead of melanoma diagnosis, and is thoroughly described in the relevant chapter of this paper (Section 4.2).

Lastly, exosomes possess enormous biomarker potential due to their tumor-originated content, which can be applied for diagnosis and tumor burden estimation, as well as for PFS prediction. The protein content of exosomes was showed to be higher in serum of melanoma patients than in healthy individuals, irrespectively of active or not evident disease. PD-1L expression on melanoma-derived exosomes was inversely associated with disease status, and they were found to be enriched with immunosuppressive proteins, most likely mediating tumor-induced immune suppression and thus hampering immunotherapy in melanoma [144]. Their tumor origin can provide a better overview of tumor heterogeneity than histological approaches since PD-1L associated with exosomes was found in the serum of all tested patients, whereas only in $67 \%$ of tumor biopsies. Moreover, exosomal PD-L1 level, although not related to tumor Breslow thickness, melanoma type, or age of the patients, was elevated in the plasma of melanoma patients compared to healthy controls [145]. The stage of melanoma did not influence the concentration of exosomes, but patients with advanced stages had a higher content of S100B and melanoma inhibitory activity (MIA) proteins per particle, which could reflect the stage, progression, and metastases [146]. Although limited, some data already exists showing that the tumor stage is represented by specific exosomal miRNAs content. Margue et al. observed the difference between exosomal miRNAs, specifically a melanocytic marker miR-211-5p, in early- vs. latestage patients [147]. Later on, Tengda et al. and Pfeffer et al., based on the increased level of exosomal miR-106b, miR-532-5p, miR-17, miR-19a, miR-21, miR-126, and miR-149 in melanoma patients compared to a healthy control group, managed to precisely distinguish tumor thickness, different melanoma stages, metastatic from non-metastatic patients, and patients receiving pembrolizumab from naïve-treatment patients [148,149]. Another study revealed that a lower level of miR-125b was attributed to advanced melanoma, probably as a result of a disturbance in tumor cells [150]. The protein set, consisting of tyrosinase- 
related protein-2 (TYRP-2), very late antigen-4 (VLA-4), heat shock protein 70 (HSP70), heat shock protein 90 (HSP90), and MET oncoprotein, was termed as an exosome-specific melanoma signature and found to be increased in stage IV patients, affecting survival and metastatic spread [62]. Similarly, differential expression of vitreal miRNAs in patients with uveal melanoma was found in comparison to healthy controls. Additionally, higher content of miR-146a was also described to be present in serum, suggesting its potential to become a non-invasive biomarker of uveal melanoma [151]. Exosomes purified from lymphatic drainage after lymphadenectomy of stage III patients contained melanoma progression-related proteins, showing that RAS/RAF/MAPK pathway-related proteins are altered depending on the volume of nodal metastases. These exosomes were also suitable for the detection of melanoma-specific mutations, like $B R A F(V 600 E)$, helping to promptly identify patients at risk of relapse caused by residual disease [152].

\subsection{Assessment of Treatment Efficacy and Acquired Resistance}

The disease progression can also be evaluated via the determination of treatment efficacy. CMC enumeration before, during, and after melanoma treatment could potentially provide crucial information about its outcome, as results of some studies have proven informative for the estimation of therapy response in melanoma.

Studies involving immunomagnetic cell enrichment of CMCs through targeting MCSP, MCAM, ABCB5, and CD271 markers were conducted prior, during, and after the treatments based on surgery, as well as vemurafenib, ipilimumab, or dacarbazine. Although numbers of detected CMCs at baseline were not a prognostic factor for OS or PFS, their low counts ( $<2$ CTCs per $1 \mathrm{~mL}$ of blood) were related to a more efficient response to vemurafenib treatment. Moreover, a decline in CMC prevalence after initiation of vemurafenib treatment was similarly associated with a faster response to therapy and longer OS [153].

It is worth noting that the CellSearch ${ }^{\circledR}$ system used for the isolation of CMCs has a great predisposition for clinical use, although currently favorable data mostly concerns patients with metastatic disease [154]. Khoja et al., using the CellSearch ${ }^{\circledR}$ system, performed sequential testing of melanoma patients treated with dacarbazine, BRAF, and MEK inhibitors, or immunotherapy with a CTLA-4 monoclonal antibody. The cut-off of $2 \mathrm{CMCs}$ at baseline was found to be prognostic for OS, with 2.6 months for patients harboring $\geq 2 \mathrm{CMCs}$ and 7.2 months for patients harboring $<2$ CMCs. Subsequent analyses during the course of the treatment showed that maintaining the number of $\geq 2 \mathrm{CMCs}$ was predictive for a shorter OS, compared to <2 CTCs (7 vs. 10 months) [75].

Koyanagi et al., using a multi-marker mRNA assay, showed that in relapse-free patients, the number of detected CMCs' markers significantly decreased after neoadjuvant biochemotherapy. Reversely, their presence after completed treatment was related to a significant decrease in relapse-free and OS rates, making them a potentially prognostic factor for OS [155]. Similarly, Reid et al., measuring MLANA, ABCB5, and MCAM transcripts in a representative group of 230 patients, found an association between the presence of the first two and disease recurrence. Furthermore, the common MCAM expression was attributed to patients poorly responding to therapy [156].

Gray et al., using multiparametric flow cytometry for analysis of melanoma (MCAM, MCSP) and tumor-infiltrating (ABCB5, CD271, RANK) marker co-expression, found that only RANK-positive cells reflected the effectiveness of BRAF/MEK-targeted therapy with vemurafenib or dabrafenib/trametinib. Interestingly, 6-13 weeks after treatment initiation, an increase in CMC numbers was observed, with the presence of at least five RANK-positive CMCs being the indicator of shorter PFS. No such relation was observed in the case of the checkpoint inhibitor treatment, making it specific for targeted therapy and underlying the involvement of RANKL/RANK axis in inhibition of MAPK kinases in melanoma [126]. Corresponding research by Khattak et al. showed that the majority of RANK- and ABCB5positive CMCs also presented PD-L1 expression. However, PD-L1-expressing CMCs were, on the contrary, associated with an effective response to treatment with PD-1 inhibitor pembrolizumab and longer PFS comparing to PD-L1-negative CMCs (26.6 vs. 5.5 months, 
respectively). The total number of CMCs was not an indicator of response to treatment or correlated with survival, making PD-L1-positive CMCs an independent prognostic factor. Lastly, both total CMCs and PD-L1-positive CMCs decreased after 6-12 months after treatment initiation in the majority of responders and increased or stayed at the same level in non-responders [157].

A previously quoted meta-analysis by Mocellin et al. remains in accordance with the abovementioned results, showing that CMC number was associated not only with TNM stage but also with both reduced OS and PFS. Nevertheless, the inconsistency in study designs and lack of standardization of detection methods resulted in substantial statistical variability [128].

Other technologies have also been applied in terms of treatment efficacy evaluation. An antibody-functionalized microfluidic platform for CMC capture was found to be useful for monitoring the efficacy of treatment with BRAF inhibitors in patients bearing the $B R A F(V 600 E)$ mutation. The decrease was found after the treatment, and CMC counts were associated with the detailed clinical status of the disease, indicating the character of the response [129].

Finally, some innovative approaches attract attention, such as CTC-derived xenografts (CDX) from individual patients. First, in vitro experiments showed that xenografts injected in mice mirrored histopathologic and immunohistochemical characteristics of a patient's tumor. Most importantly, CDX-bearing mice, similarly to the patient, developed molecularly compatible human melanoma metastases and similar responses, or lack thereof, to the same treatment with vemurafenib and dabrafenib. Thus, CDXs could be a future-proof tool for drug efficacy testing, predicting response to treatment and helping to drive personalized treatment decisions for advanced-stage melanoma patients [158].

In contrast to differentiated results regarding CMC use in treatment monitoring, ctDNA detection was found to strongly correlate with the clinical status of the patients, according to multiple studies. An association was presented between ctDNA and tumor burden $[92,159,160]$, manifested via CT scans and serological markers like lactate dehydrogenase (LDH), S100B, and MIA. The advantage of ctDNA detection for melanoma tracking is its tumor origin, which is not affected by non-specific inflammatory conditions. This designates ctDNA as a reliable liquid biopsy biomarker for clinical cancer management [134].

These findings are especially valuable in terms of the assessment of $B R A F(V 600 E)$ mutation for monitoring of patients treated with BRAF/MEK inhibitors. Girotti et al. showed that ctDNA reflected the response to treatment with dabrafenib/trametinib. The concentration of $B R A F(V 600 E) \mathrm{ctDNA}$ decreased along with tumor reduction and increased in a case of relapse. Higher ctDNA levels also mirrored the lack of response to other therapeutic agents, such as ipilimumab. Moreover, monitoring of ctDNA levels was predictive for treatment outcome, reflecting unsuccessful treatment with ipilimumab one week prior to CT scan and successful treatment with dabrafenib/trametinib six weeks prior to CT scan. Importantly, with the use of the WES method, the resistance mechanism was also determined. Despite BRAF inhibition, the MAPK pathway can be activated due to mutations in the NRAS gene, promoting tumor survival [161]. Using a panel of ten loci, ctDNA-targeted sequencing managed to detect $N R A S(Q 61 K), N R A S(Q 61 R)$, and PIK3CA(E545K) mutations, known to mediate resistance to BRAF/MEK inhibitors, even several weeks before the scan [158].

The beneficial impact of ctDNA testing in terms of treatment monitoring was confirmed by other study groups with the use of PCR-based methods. Quantification of $B R A F(V 600 E)$ ctDNA prior to and during the course of treatment with dabrafenib and vemurafenib mirrored its outcome, decreasing significantly at the moment of the strongest response while increasing significantly in the event of progression [134]. Moreover, the groups of Schreuer et al. and Grey et al. obtained concordant results [45,133], the latter additionally showing that, even in patients defined as non-responders, reduced levels of ctDNA were associated with extended PFS, indicating a positive effect of the treatment. 
Furthermore, baseline ctDNA concentrations were associated with subsequent response to therapy in patients treated with BRAF/MEK inhibitors (dabrafenib, trametinib, vemurafenib), as well as the length of PFS. However, some patients with higher baseline ctDNA concentrations were treatment-responders and had a PFS longer than six months, underlining the fact that a low level of ctDNA at the baseline, although prognostic, is not a unique indicator of a clinically beneficial response to treatment [45]. In patients with acquired resistance to BRAF inhibitors, mutations in the NRAS gene (NRAS(Q61K) and $N R A S(Q 61 R))$ have been detected and positively correlated with an increase in BRAF mutant ctDNA [45].

Brain metastases occur in the majority of melanoma patients, posing a significant clinical challenge. Thus, determination of a ctDNA predictive value in their management is crucial. Gray et al. revealed that the development of brain metastases was the only exception when the measurement of ctDNA was not conclusive for progression detection [45]. Similarly, in-depth studies of Lee et al. found that ctDNA cannot be treated as a reliable tool in the case of intracranial response evaluation, since neither baseline nor on-therapy ctDNA predicted the intracranial response rate [135]. This phenomenon can be theoretically explained by the fact that the blood-brain barrier can hamper ctDNA passage to the bloodstream and thus undermine its clinical value [162]. On the other hand, brain metastatic patients with undetectable ctDNA prior to and during the therapy presented improved OS compared to those with detectable ctDNA levels (39.2 vs. 10.6 months and 39.2 vs. 9.2 months, respectively), regardless of intracranial treatment response. Interestingly, the OS of patients with brain metastases and undetectable ctDNA was comparable to the OS of patients with extracranial metastases and detectable ctDNA caused by a lower intracranial response to treatment [135].

Results of Ascierto et al., obtained with the use of BEAMing technology, confirmed the abovementioned data, finding a relation between baseline and follow-up BRAF(V600E) ctDNA levels and tumor burden, response to treatment with BRAF inhibitors, prediction of disease progression prior to CT scan, and PFS. Furthermore, the detection of resistance mutations successfully predicted the development of resistance to BRAF inhibitor therapy [163].

The study of Santiago-Walker et al., collecting data from four clinical trials and a large study cohort of 836 patients, seems to conclude the abovementioned findings. BRAF mutations in ctDNA of late-stage melanoma patients were consistent with more than $75 \%$ of BRAF mutated tumors. The presence of ctDNA, carrying BRAF mutations, was clinically relevant and predicted a worse course of the disease. Based on this, ctDNA was defined as a reliable prognostic tool for monitoring of response to targeted treatment in melanoma patients [164].

Detection of ctDNA was proved also to be suitable for monitoring of patients receiving immunotherapy. Research by Valpione et al., conducted on metastatic melanoma patients, confirmed that baseline ctDNA concentration reflected tumor burden, with their ratio possessing a prognostic value. Increased ctDNA concentration correlated with shorter OS (8.5 vs. 22.7 months) and risk of death. A significant correlation was also found between changes in ctDNA level and tumor burden observed in the course of treatment with CTLA-4 (ipilimumab) and PD-1 (nivolumab) inhibitors [40,165]. A low level of ctDNA in treatment-naïve patients was also linked to effective response in patients treated with ipilimumab, nivolumab, and pembrolizumab and improved PFS. However, the decrease in ctDNA after the commencement of therapy was not often observed in patients receiving immunotherapy. Nevertheless, while some of those that presented substantial ctDNA decrease were qualified as non-responders, the disease was stable for the next six months, indicating that ctDNA somehow reflected the effectiveness of the treatment. Lack of response to immunotherapy, following the failure of BRAF/MEK inhibitors administration, was concordant with the persistent presence of ctDNA during and at the end of treatment [45]. Similarly, longitudinal testing of ctDNA in patients treated with CTLA-4 and PD-1 inhibitors revealed that patients presenting undetectable levels of ctDNA after 
initiation of treatment had a higher response rate, PFS, and OS in comparison to those with detectable levels, irrespective of baseline ctDNA status $[40,166,167]$. Importantly, ctDNA as a time-dependent variable was superior to LDH testing in predicting 12-month survival [166]. In addition, ctDNA profiles in patients treated with anti-PD-1 antibody allowed differentiation of patients with pseudo-progression from patients with true disease progression with a sensitivity of $90 \%$ and specificity of $100 \%$, showing higher positive and negative values than LDH [168]. Identification of pseudo-progression, defined as infiltration of the tumor by lymphocytes, giving the impression of an enlarged tumor in $\mathrm{CT}$ scans, is both challenging and of great importance in this group of patients since it can prevent termination of potentially effective treatment and may guide further therapeutic decisions [44]. ctDNA was also found to be a better prognostic factor than LDH in the studies conducted by Chang et al. [169] and Valpione et al. [165], as well as better than S100 in the studies by Váraljai et al. [93] and Braune et al. [160].

All this taken together indicates that detection of tumor-associated ctDNA is a reliable and simple approach for the evaluation of response to treatment, including resistance evolution.

Treatment response can also be assessed with the use of exosomes. It was demonstrated that the level of exosomal PD-L1 differed along the course of anti-PD-1 treatment and assisted in the stratification of patients into groups of responders and non-responders for anti-PD-1 therapy. A higher level of exosomal PD-L1 in serum was attributed to non-responding patients and progression, while a lower level was linked to response to treatment. This suggested that adaptive upregulation of PD-L1 expression in exosomes could impede proliferation and cytotoxicity of T cells, evading anti-tumoral immune response $[145,170]$. Similarly, a decrease in exosomal PD-L1 mRNA reflected a response to anti-PD-1 treatment and was consistent with CT scan results [171]. Conversely, an increase in exosomal PD-1 was characteristic for patients responding to anti-CTLA-4 therapy with improved OS and PFS. Results obtained in respect to PD-1 and CTLA-4 indicate exosomes as effective biomarkers for monitoring of immune checkpoint inhibitorbased therapies [172]. Furthermore, in the serum of patients harboring the BRAF(V600E) mutation, exosomal miRNA content differed before and after therapy with BRAF/MEK inhibitors. Particularly, an increase of let-7g-5p and miR-497-5p miRNAs was noted during the therapy, corresponding to treatment response and prolonged PFS, respectively [173]. It was also speculated, based on in vitro studies, that melanoma-derived exosomes were also involved in resistance acquisition against BRAF inhibitors, with their participation mediated by the transport of resistance driver-platelet-derived growth factor $\beta$ (PDGFR $\beta$ ) to adjacent BRAF inhibitor sensitive cells [65] or by the melanocyte inducing transcription factor (MITF)-mediated upregulation of miR-211-5p, known to reduce sensitivity to BRAF inhibitors [174]. However, further research is needed to confirm this theory in the clinical setting.

\subsection{Completed and Ongoing Clinical Trials}

Liquid biopsy is not widely used in the clinical practice of melanoma due to insufficient validation of research results. The most up-to-date source of completed and ongoing clinical trials using liquid biopsy in melanoma is the ClinicalTrials.gov database [175]. Table 1 summarizes completed studies on CMCs and ctDNA in melanoma, while Table 2 presents those that are still ongoing. During recent years, some of the studies also included the detection of EVs such as exosomes as a promising source of clinically relevant information.

The high heterogeneity of CMCs and the multitude of used detection methodologies among different study groups impede the widespread application of CMCs as a biomarker of melanoma in clinical practice. Nevertheless, there are some completed and ongoing clinical trials aiming at better standardization and future implementation of CMCs detection and characterization technologies. 
Table 1. Completed clinical studies on circulating melanoma cells and circulating tumor DNA (based on ClinicalTrials.gov (accessed on 7 June 2021)).

\begin{tabular}{|c|c|c|c|c|c|}
\hline No. & NCT No. & Study Title & Cancer & Location & $\begin{array}{c}\text { Participants } \\
\text { (Active/Original) }\end{array}$ \\
\hline 1. & NCT01573494 & $\begin{array}{l}\text { Study of Circulating Tumor Cells } \\
\text { Before and After Treatment in } \\
\text { Patients With Metastatic Melanoma }\end{array}$ & $\begin{array}{l}\text { Metastatic } \\
\text { melanoma }\end{array}$ & CHU of Nice, Nice, France & $30 / 30$ \\
\hline 2. & NCT01558349 & $\begin{array}{l}\text { Circulating Tumor Cells and } \\
\text { Melanoma: Comparing the } \\
\text { EPISPOT and CellSearch } \\
\text { Techniques }\end{array}$ & $\begin{array}{l}\text { Metastatic } \\
\text { melanoma }\end{array}$ & $\begin{array}{c}\text { CHU of Montpellier, } \\
\text { Montpellier, France } \\
\text { CHU of Nîmes, Nîmes, France }\end{array}$ & $73 / 82$ \\
\hline 3. & NCT01528774 & $\begin{array}{l}\text { Culture and Characterization of } \\
\text { Circulating Tumor Cells (CTC) in } \\
\text { Melanoma and Other Cancers }\end{array}$ & $\begin{array}{l}\text { Melanoma and } \\
\text { other cancers }\end{array}$ & $\begin{array}{c}\text { Comprehensive Cancer Centers } \\
\text { of Nevada Las Vegas, Nevada, } \\
\text { United States }\end{array}$ & $150 / 1000$ \\
\hline 4. & NCT02133222 & $\begin{array}{l}\text { Circulating Cell-free DNA in } \\
\text { Metastatic Melanoma Patient: } \\
\text { Mutational Analyses in Consecutive } \\
\text { Measurement Before and After } \\
\text { Chemotherapy }\end{array}$ & $\begin{array}{l}\text { Metastatic } \\
\text { melanoma }\end{array}$ & $\begin{array}{l}\text { CHU of Nice } \\
\text { Nice, France }\end{array}$ & $22 / 20$ \\
\hline 5. & NCT03007823 & $\begin{array}{l}\text { High-Activity Natural Killer } \\
\text { Immunotherapy for Small } \\
\text { Metastases of Melanoma }\end{array}$ & $\begin{array}{l}\text { Metastatic } \\
\text { melanoma }\end{array}$ & $\begin{array}{l}\text { Fuda Cancer Institute of Fuda } \\
\text { Cancer Hospital Guangzhou, } \\
\text { Guangdong, China }\end{array}$ & $20 / 20$ \\
\hline 6. & NCT02768207 & $\begin{array}{c}\text { A Study to Detect V-Raf Murine } \\
\text { Sarcoma Viral } \\
\text { Oncogene Homolog B1 (BRAF) } \\
\text { V600 Mutation on } \\
\text { Cell-Free Deoxyribonucleic Acid } \\
\text { (cfDNA) from } \\
\text { Plasma in Participants with } \\
\text { Advanced Melanoma }\end{array}$ & $\begin{array}{l}\text { Metastatic } \\
\text { melanoma }\end{array}$ & $\begin{array}{l}\text { UZ Brussel, Brussel, Belgium } \\
\text { Institute Jules Bordet, Brussel, } \\
\text { Belgium } \\
\text { CHIREC Edith Cavell, Brussel, } \\
\text { Belgium } \\
\text { (and } 11 \text { more ... ) }\end{array}$ & $40 / 208$ \\
\hline 7. & NCT02251314 & $\begin{array}{c}\text { Use of Exome Sequence Analysis } \\
\text { and Circulating } \\
\text { Tumor in Assessing Tumor } \\
\text { Heterogeneity in BRAF } \\
\text { Mutant Melanoma }\end{array}$ & $\begin{array}{l}\text { BRAF-mutated } \\
\text { melanoma }\end{array}$ & $\begin{array}{l}\text { Princess Margaret Cancer } \\
\text { Centre } \\
\text { Toronto, Ontario, Canada }\end{array}$ & $12 / 6$ \\
\hline
\end{tabular}

Several clinical studies related to CMCs describe their level before and after the use of immunotherapy, especially BRAF inhibitors. The research conducted at CHU de Nice, France, was aimed at defining a group of patients with positive CMC detection and finding the relationship between the number of CMCs and their prognostic significance. The study implemented the CellSearch ${ }^{\circledR}$ system to elucidate the differences in patient survival in relation to the number of CMCs (Table 1). A similar observational, prospective pilot study based on the same assumptions is currently being conducted by Vanna Chiarion-Sileni (Padova, Italy), determining the change of CMC number before and after treatment in the whole blood of metastatic melanoma patients (Table 2).

Another study worth mentioning is the comparison of the CellSearch ${ }^{\circledR}$ system and viable cells detecting S100-EPISPOT technology (Table 1). Detection of CMCs compared among patients with advanced melanoma and the control group revealed that even though the CellSearch ${ }^{\circledR}$ method turned out to be more prognostic (only in this case a significant relationship with the overall survival was shown), S100-EPISPOT was significantly more sensitive, as the percentage of patients harboring $\geq 2 \mathrm{CMC}$ was higher. The higher sensitivity of this technology indicates its likely potential for early detection of recurrence and treatment monitoring [20].

Interestingly, there is an ongoing in vivo clinical trial being conducted at the University of Arkansas. The scientists are using the photoacoustic flow cytometry (PAFC)-based prototype method to detect CMCs in three study groups consisting of healthy individuals, patients with advanced melanoma, and patients with early melanoma. The control group serves to establish the baseline. The second group is used to validate the method and the last to test the method's ability to find CMC below the detection limit. The study is in 
the recruitment phase and hopefully will provide some valuable data in the near future (Table 2).

Table 2. Ongoing clinical studies on circulating melanoma cells and circulating tumor DNA (based on ClinicalTrials.gov (accessed on 7 June 2021)).

\begin{tabular}{|c|c|c|c|c|c|}
\hline No. & NCT No. & Study Title & Cancer & Location & $\begin{array}{l}\text { Participants } \\
\text { (Estimated) }\end{array}$ \\
\hline 1. & NCT01776905 & $\begin{array}{l}\text { In Vivo Real-Time Detection of } \\
\text { Circulating Melanoma Cells }\end{array}$ & $\begin{array}{l}\text { Melanoma stage } \\
\text { I-IV }\end{array}$ & $\begin{array}{l}\text { University of Arkansas for } \\
\text { Medical Sciences } \\
\text { Little Rock, Arkansas, United } \\
\text { States }\end{array}$ & 75 \\
\hline 2. & NCT03808441 & $\begin{array}{c}\text { CAcTUS-Circulating Tumour DNA } \\
\text { Guided Switch }\end{array}$ & $\begin{array}{l}\text { Metastatic } \\
\text { melanoma }\end{array}$ & $\begin{array}{c}\text { The Christie NHS Foundation } \\
\text { Trust } \\
\text { Manchester, United Kingdom }\end{array}$ & 40 \\
\hline 3. & NCT03416933 & $\begin{array}{l}\text { Therapeutic Drug Monitoring of } \\
\text { BRAF-Mutated Advanced Melanoma }\end{array}$ & $\begin{array}{l}\text { Metastatic } \\
\text { melanoma }\end{array}$ & $\begin{array}{c}\text { Hôpital de Mercy, } \\
\text { Ars-Laquenexy, Fr CHRU } \\
\text { Nancy, Vandœuvre-lès-Nancy, } \\
\text { Fr Institut de Cancérologie de } \\
\text { Lorraine (ICL), } \\
\text { Vandœuvre-lès-Nancy, Fr }\end{array}$ & 35 \\
\hline 4. & NCT03797053 & $\begin{array}{c}\text { Ex Vivo Expansion of Circulating Tumor } \\
\text { Cells as a Model for Cancer Predictive } \\
\text { Pharmacology }\end{array}$ & $\begin{array}{l}\text { Melanoma stage } \\
\text { III-IV }\end{array}$ & $\begin{array}{l}\text { Saint-Louis Hospital } \\
\text { Paris, France }\end{array}$ & 450 \\
\hline 5. & NCT01565837 & $\begin{array}{c}\text { Concurrent Ipilimumab and Stereotactic } \\
\text { Ablative } \\
\text { Radiation Therapy (SART) for } \\
\text { Oligometastatic but } \\
\text { Unresectable Melanoma }\end{array}$ & $\begin{array}{l}\text { Melanoma stage } \\
\text { III-IV }\end{array}$ & $\begin{array}{c}\text { Comprehensive Cancer Centers } \\
\text { of Nevada Las Vegas, Nevada, } \\
\text { United States }\end{array}$ & 50 \\
\hline 6. & NCT02862743 & $\begin{array}{l}\text { Molecular Characterization of } \\
\text { Advanced Stage } \\
\text { Melanoma by Blood Sampling }\end{array}$ & $\begin{array}{l}\text { Metastatic } \\
\text { melanoma }\end{array}$ & CHU of Reims Reims, France & 80 \\
\hline 7. & NCT01878396 & $\begin{array}{c}\text { Circulating Melanoma Cells in } \\
\text { Metastatic Patients } \\
\text { Treated with Selective BRAF Inhibitors }\end{array}$ & $\begin{array}{l}\text { Metastatic } \\
\text { melanoma }\end{array}$ & $\begin{array}{c}\text { Istituto Oncologico Veneto } \\
\text { IRCCS } \\
\text { Padova, Italy }\end{array}$ & 200 \\
\hline 8. & NCT02583516 & $\begin{array}{l}\text { Clinical Trial to Evaluate the Efficacy of } \\
\text { Vemurafenib } \\
\text { in Combination with Cobimetinib } \\
\text { (Continuous and } \\
\text { Intermittent) in } \\
\text { BRAFV600-Mutation-Positive } \\
\text { Patients With Unresectable Locally } \\
\text { Advanced or } \\
\text { Metastatic Melanoma }\end{array}$ & $\begin{array}{l}\text { Melanoma stage } \\
\text { III-IV }\end{array}$ & $\begin{array}{c}\text { Hospital Universitario } \\
\text { Donostia, San Sebastián, } \\
\text { Guipuzcoa, Spain } \\
\text { Hospital General Universitario } \\
\text { Santa Lucía, } \\
\text { Cartagena, Murcia, Spain } \\
\text { Hospital Clínic de Barcelona, } \\
\text { Barcelona, Spain } \\
\text { (and } 15 \text { more ... ) }\end{array}$ & 70 \\
\hline 9. & NCT03175432 & $\begin{array}{c}\text { Bevacizumab and Atezolizumab with or } \\
\text { without } \\
\text { Cobimetinib in Treating Patients with } \\
\text { Untreated } \\
\text { Melanoma Brain Metastases }\end{array}$ & $\begin{array}{l}\text { Metastatic } \\
\text { melanoma }\end{array}$ & $\begin{array}{l}\text { MD Anderson Cancer Center } \\
\text { Houston, Texas, United States }\end{array}$ & 60 \\
\hline 10. & NCT03873818 & $\begin{array}{c}\text { Low-Dose Ipilimumab With } \\
\text { Pembrolizumab in } \\
\text { Treating Patients with Melanoma that } \\
\text { has Spread to } \\
\text { the Brain }\end{array}$ & $\begin{array}{l}\text { Metastatic } \\
\text { melanoma and } \\
\text { other cancers }\end{array}$ & $\begin{array}{l}\text { MD Anderson Cancer Center } \\
\text { Houston, Texas, United States }\end{array}$ & 30 \\
\hline 11. & NCT02537600 & $\begin{array}{l}\text { Vemurafenib and Cobimetinib } \\
\text { Combination in BRAF } \\
\text { Mutated Melanoma with Brain } \\
\text { Metastasis }\end{array}$ & $\begin{array}{l}\text { Metastatic } \\
\text { melanoma }\end{array}$ & $\begin{array}{c}\text { CHU of Bordeaux, Bordeaux, } \\
\text { France } \\
\text { CHU Ambroise Paré, Boulogne, } \\
\text { France } \\
\text { CHU Brest Hôpital Morvan, } \\
\text { Brest, France } \\
\text { (and } 14 \text { more ... ) }\end{array}$ & 43 \\
\hline 12. & NCT02673970 & $\begin{array}{c}\text { Biomarkers for the Activity of Immune } \\
\text { Checkpoint } \\
\text { Inhibitor Therapy in Patients with } \\
\text { Advanced Melanoma }\end{array}$ & $\begin{array}{l}\text { Metastatic } \\
\text { melanoma }\end{array}$ & $\begin{array}{l}\text { UZ Brussel Jette, Brabant, } \\
\text { Belgium }\end{array}$ & 200 \\
\hline
\end{tabular}


Moreover, the available studies include a comparison of CMC immunophenotyping and analysis of somatic melanoma DNA mutations. The predominant aim was the evaluation of CMC isolation with the TrueCells technology and the correlation of the results with those of immunofluorescence staining (Table 1).

ctDNA has also been a subject of clinical trials, both completed and still ongoing. A study based on samples from patients with advanced melanoma (stage IV) analyzed with the next generation sequencing technology (Sequenom Mass Array) examined the ctDNA mutations before and after chemotherapy. The additive value of this study is a double analysis conducted after the first chemotherapy administration and following three months, which provides information about treatment response (Table 1).

As far as ongoing clinical trials are concerned, there are a few notable examples. The CAcTUS pilot study (Table 2) is expected to provide information on changes in ctDNA levels, which will be used to define the moment of the switch from targeted therapy to immunotherapy. Continuing, the relationship between the presence of circulating tumor DNA and plasma levels of kinase inhibitors in patients with advanced $B R A F(V 600)$ mutant melanoma is being investigated in a study entitled "Therapeutic Drug Monitoring of BRAF-mutated Advanced Melanoma" (Table 2). Metastatic melanoma is frequently treated with a combination of anti-BRAF and anti-MEK tyrosine kinase inhibitors. The aim of the OPTIMEL study is to investigate the possibility of metastatic melanoma monitoring with the measurement of ctDNA levels in thirty-five patients with advanced melanoma treated with a combination of dabrafenib and trametinib. The next clinical trial, titled "Use of Exome Sequence Analysis and Circulating Tumour in Assessing Tumour Heterogeneity in BRAF Mutant Melanoma", concerns the evolution of BRAF melanoma in response to vemurafenib or dabrafenib. It will determine the development of tumor resistance against these drugs based on ctDNA analysis.

\section{Conclusions}

Liquid biopsy allows crucial clinical information to be obtained using a significantly less invasive approach. Hence, the use of the described biomarkers in routine melanoma diagnosis and control of systemic therapy in melanoma patients should be considered. CMCs may be an indicator of residual disease, thus signalizing a worse prognosis for positive patients [176]. Moreover, using the information collected from CMCs, ctDNA, and $\mathrm{mRNA} / \mathrm{miRNA}$, it is possible to observe real-time changes in the tumor based on CMC number, their gene expression, and possible mutations [177]. Furthermore, quantification of S100 proteins could potentially be used in the diagnosis, monitoring, and treatment of melanoma [178]. Finally, the research into cancer exosomes has the potential to help to understand the mechanisms of drug resistance, potentially aiding the improvement of treatment effectiveness.

Author Contributions: P.K.-manuscript writing; K.B.-data collection; M.Z.-funding; M.N.manuscript revision; C.A.-P.-manuscript revision; J.B.-T.-manuscript design and writing. All authors have read and agreed to the published version of the manuscript.

Funding: This research was funded by The National Institute of Cancer (INCa, http:/ / www.e-cancer. fr (accessed on 7 June 2011)), by the SIRIC Montpellier Cancer Grant INCa_Inserm_DGOS_12553, the European Union Horizon 2020 Research and Innovation program under the Marie Skłodowska-Curie grant agreement No 765492m as well as the ERA-NET TRANSCAN 2 JTC 2016 PROLIPSY—Fondation ARC pour la recherche sur le cancer and The National Centre for Research and Development No ERA-NET-TRANSCAN/01/2018 "PROLIPSY".

Conflicts of Interest: Catherine Alix-Panabières received honoraria from Menarini. 


\section{References}

1. Bray, F.; Ferlay, J.; Soerjomataram, I.; Siegel, R.L.; Torre, L.A.; Jemal, A. Global Cancer Statistics 2018: GLOBOCAN Estimates of Incidence and Mortality Worldwide for 36 Cancers in 185 Countries. CA Cancer J. Clin. 2018, 68, 394-424. [CrossRef] [PubMed]

2. Rastrelli, M.; Tropea, S.; Rossi, C.R.; Alaibac, M. Melanoma: Epidemiology, Risk Factors, Pathogenesis, Diagnosis and Classification. In Vivo 2014, 28, 1005-1011.

3. Joyce, K.M. Surgical Management of Melanoma. In Cutaneous Melanoma: Etiology and Therapy; Ward, W.H., Farma, J.M., Eds.; Codon Publications: Brisbane, Australia, 2017; ISBN 978-0-9944381-4-0.

4. Lugowska, I.; Teterycz, P.; Rutkowski, P. Immunotherapy of Melanoma. Contemp. Oncol. Poznan Pol. 2018, 22, 61-67. [CrossRef] [PubMed]

5. Callahan, M.K.; Wolchok, J.D.; Allison, J.P. Anti-CTLA-4 Antibody Therapy: Immune Monitoring during Clinical Development of a Novel Immunotherapy. Semin. Oncol. 2010, 37, 473-484. [CrossRef]

6. Melero, I.; Grimaldi, A.M.; Perez-Gracia, J.L.; Ascierto, P.A. Clinical Development of Immunostimulatory Monoclonal Antibodies and Opportunities for Combination. Clin. Cancer Res. Off. J. Am. Assoc. Cancer Res. 2013, 19, 997-1008. [CrossRef]

7. Robert, C.; Schachter, J.; Long, G.V.; Arance, A.; Grob, J.J.; Mortier, L.; Daud, A.; Carlino, M.S.; McNeil, C.; Lotem, M.; et al. Pembrolizumab versus Ipilimumab in Advanced Melanoma. N. Engl. J. Med. 2015, 372, 2521-2532. [CrossRef]

8. Siegel, R.L.; Miller, K.D.; Jemal, A. Cancer Statistics, 2020. CA Cancer J. Clin. 2020, 70, 7-30. [CrossRef]

9. Mader, S.; Pantel, K. Liquid Biopsy: Current Status and Future Perspectives. Oncol. Res. Treat. 2017, 40, 404-408. [CrossRef]

10. Blanco, B.A.; Wolfgang, C.L. Liquid Biopsy for the Detection and Management of Surgically Resectable Tumors. Langenbecks Arch. Surg. 2019, 404, 517-525. [CrossRef]

11. Cabel, L.; Proudhon, C.; Gortais, H.; Loirat, D.; Coussy, F.; Pierga, J.-Y.; Bidard, F.-C. Circulating Tumor Cells: Clinical Validity and Utility. Int. J. Clin. Oncol. 2017, 22, 421-430. [CrossRef]

12. Pantel, K.; Alix-Panabières, C. Liquid Biopsy and Minimal Residual Disease-Latest Advances and Implications for Cure. Nat. Rev. Clin. Oncol. 2019, 16, 409-424. [CrossRef] [PubMed]

13. Poulet, G.; Massias, J.; Taly, V. Liquid Biopsy: General Concepts. Acta Cytol. 2019, 63, 449-455. [CrossRef]

14. Merker, J.D.; Oxnard, G.R.; Compton, C.; Diehn, M.; Hurley, P.; Lazar, A.J.; Lindeman, N.; Lockwood, C.M.; Rai, A.J.; Schilsky, R.L.; et al. Circulating Tumor DNA Analysis in Patients With Cancer: American Society of Clinical Oncology and College of American Pathologists Joint Review. J. Clin. Oncol. Off. J. Am. Soc. Clin. Oncol. 2018, 36, 1631-1641. [CrossRef] [PubMed]

15. Pantel, K.; Alix-Panabières, C. Circulating Tumour Cells in Cancer Patients: Challenges and Perspectives. Trends Mol. Med. 2010, 16, 398-406. [CrossRef] [PubMed]

16. Pantel, K.; Hille, C.; Scher, H.I. Circulating Tumor Cells in Prostate Cancer: From Discovery to Clinical Utility. Clin. Chem. 2019, 65, 87-99. [CrossRef] [PubMed]

17. Alix-Panabières, C.; Pantel, K. Liquid Biopsy: From Discovery to Clinical Application. Cancer Discov. 2021, 11, 858-873. [CrossRef]

18. Alix-Panabières, C.; Schwarzenbach, H.; Pantel, K. Circulating Tumor Cells and Circulating Tumor DNA. Annu. Rev. Med. 2012, 63, 199-215. [CrossRef]

19. Xu, M.J.; Dorsey, J.F.; Amaravadi, R.; Karakousis, G.; Simone, C.B.; Xu, X.; Xu, W.; Carpenter, E.L.; Schuchter, L.; Kao, G.D. Circulating Tumor Cells, DNA, and MRNA: Potential for Clinical Utility in Patients With Melanoma. Oncologist 2016, 21, 84-94. [CrossRef]

20. Cayrefourcq, L.; De Roeck, A.; Garcia, C.; Stoebner, P.-E.; Fichel, F.; Garima, F.; Perriard, F.; Daures, J.-P.; Meunier, L.; Alix-Panabières, C. S100-EPISPOT: A New Tool to Detect Viable Circulating Melanoma Cells. Cells 2019, 8, 755. [CrossRef] [PubMed]

21. Weight, R.M.; Viator, J.A. Detection of Circulating Tumor Cells by Photoacoustic Flowmetry. Methods Mol. Biol. Clifton NJ 2014, 1102, 655-663. [CrossRef]

22. Alix-Panabières, C.; Mader, S.; Pantel, K. Epithelial-Mesenchymal Plasticity in Circulating Tumor Cells. J. Mol. Med. Berl. Ger. 2017, 95, 133-142. [CrossRef] [PubMed]

23. Tayoun, T.; Faugeroux, V.; Oulhen, M.; Aberlenc, A.; Pawlikowska, P.; Farace, F. CTC-Derived Models: A Window into the Seeding Capacity of Circulating Tumor Cells (CTCs). Cells 2019, 8, 1145. [CrossRef] [PubMed]

24. Marsavela, G.; Aya-Bonilla, C.A.; Warkiani, M.E.; Gray, E.S.; Ziman, M. Melanoma Circulating Tumor Cells: Benefits and Challenges Required for Clinical Application. Cancer Lett. 2018, 424, 1-8. [CrossRef]

25. Rapanotti, M.C.; Campione, E.; Spallone, G.; Orlandi, A.; Bernardini, S.; Bianchi, L. Minimal Residual Disease in Melanoma: Circulating Melanoma Cells and Predictive Role of MCAM/MUC18/MelCAM/CD146. Cell Death Discov. 2017, 3, 17005. [CrossRef]

26. De Giorgi, V.; Pinzani, P.; Salvianti, F.; Panelos, J.; Paglierani, M.; Janowska, A.; Grazzini, M.; Wechsler, J.; Orlando, C.; Santucci, M.; et al. Application of a Filtration- and Isolation-by-Size Technique for the Detection of Circulating Tumor Cells in Cutaneous Melanoma. J. Investig. Dermatol. 2010, 130, 2440-2447. [CrossRef]

27. Long, E.; Ilie, M.; Bence, C.; Butori, C.; Selva, E.; Lalvée, S.; Bonnetaud, C.; Poissonnet, G.; Lacour, J.-P.; Bahadoran, P.; et al. High Expression of TRF2, SOX10, and CD10 in Circulating Tumor Microemboli Detected in Metastatic Melanoma Patients. A Potential Impact for the Assessment of Disease Aggressiveness. Cancer Med. 2016, 5, 1022-1030. [CrossRef] [PubMed] 
28. Hou, J.-M.; Krebs, M.; Ward, T.; Sloane, R.; Priest, L.; Hughes, A.; Clack, G.; Ranson, M.; Blackhall, F.; Dive, C. Circulating Tumor Cells as a Window on Metastasis Biology in Lung Cancer. Am. J. Pathol. 2011, 178, 989-996. [CrossRef]

29. Ma, J.; Frank, M.H. Isolation of Circulating Melanoma Cells. Methods Mol. Biol. Clifton NJ 2015. [CrossRef]

30. Campoli, M.R.; Chang, C.-C.; Kageshita, T.; Wang, X.; McCarthy, J.B.; Ferrone, S. Human High Molecular Weight-MelanomaAssociated Antigen (HMW-MAA): A Melanoma Cell Surface Chondroitin Sulfate Proteoglycan (MSCP) with Biological and Clinical Significance. Crit. Rev. Immunol. 2004, 24, 267-296. [CrossRef]

31. Bennaceur, K.; Popa, I.; Portoukalian, J.; Berthier-Vergnes, O.; Péguet-Navarro, J. Melanoma-Derived Gangliosides Impair Migratory and Antigen-Presenting Function of Human Epidermal Langerhans Cells and Induce Their Apoptosis. Int. Immunol. 2006, 18, 879-886. [CrossRef]

32. Gaiser, M.R.; von Bubnoff, N.; Gebhardt, C.; Utikal, J.S. Liquid Biopsy to Monitor Melanoma Patients. J. Dtsch. Dermatol. Ges. J. Ger. Soc. Dermatol. JDDG 2018, 16, 405-414. [CrossRef] [PubMed]

33. Bresnick, A.R.; Weber, D.J.; Zimmer, D.B. S100 Proteins in Cancer. Nat. Rev. Cancer 2015, 15, 96-109. [CrossRef]

34. Mandel, P.; Metais, P. Nuclear Acids In Human Blood Plasma. C. R. Seances Soc. Biol. Fil. 1948, 142, 241-243. [PubMed]

35. Zhang, L.; Liang, Y.; Li, S.; Zeng, F.; Meng, Y.; Chen, Z.; Liu, S.; Tao, Y.; Yu, F. The Interplay of Circulating Tumor DNA and Chromatin Modification, Therapeutic Resistance, and Metastasis. Mol. Cancer 2019, 18, 36. [CrossRef]

36. Stroun, M.; Lyautey, J.; Lederrey, C.; Olson-Sand, A.; Anker, P. About the Possible Origin and Mechanism of Circulating DNA Apoptosis and Active DNA Release. Clin. Chim. Acta Int. J. Clin. Chem. 2001, 313, 139-142. [CrossRef]

37. Phallen, J.; Sausen, M.; Adleff, V.; Leal, A.; Hruban, C.; White, J.; Anagnostou, V.; Fiksel, J.; Cristiano, S.; Papp, E.; et al. Direct Detection of Early-Stage Cancers Using Circulating Tumor DNA. Sci. Transl. Med. 2017, 9, eaan2415. [CrossRef] [PubMed]

38. Underhill, H.R.; Kitzman, J.O.; Hellwig, S.; Welker, N.C.; Daza, R.; Baker, D.N.; Gligorich, K.M.; Rostomily, R.C.; Bronner, M.P.; Shendure, J. Fragment Length of Circulating Tumor DNA. PLoS Genet. 2016, 12, e1006162. [CrossRef] [PubMed]

39. Sacher, A.G.; Paweletz, C.; Dahlberg, S.E.; Alden, R.S.; O'Connell, A.; Feeney, N.; Mach, S.L.; Jänne, P.A.; Oxnard, G.R. Prospective Validation of Rapid Plasma Genotyping for the Detection of EGFR and KRAS Mutations in Advanced Lung Cancer. JAMA Oncol. 2016, 2, 1014-1022. [CrossRef] [PubMed]

40. Forschner, A.; Battke, F.; Hadaschik, D.; Schulze, M.; Weißgraeber, S.; Han, C.-T.; Kopp, M.; Frick, M.; Klumpp, B.; Tietze, N.; et al. Tumor Mutation Burden and Circulating Tumor DNA in Combined CTLA-4 and PD-1 Antibody Therapy in Metastatic MelanomaResults of a Prospective Biomarker Study. J. Immunother. Cancer 2019, 7, 180. [CrossRef] [PubMed]

41. Stewart, C.M.; Tsui, D.W.Y. Circulating Cell-Free DNA for Non-Invasive Cancer Management. Cancer Genet. 2018, 228-229, 169-179. [CrossRef]

42. Alexandrov, L.B.; Nik-Zainal, S.; Wedge, D.C.; Aparicio, S.A.J.R.; Behjati, S.; Biankin, A.V.; Bignell, G.R.; Bolli, N.; Borg, A.; Børresen-Dale, A.-L.; et al. Signatures of Mutational Processes in Human Cancer. Nature 2013, 500, 415-421. [CrossRef]

43. Butler, T.M.; Spellman, P.T.; Gray, J. Circulating-Tumor DNA as an Early Detection and Diagnostic Tool. Curr. Opin. Genet. Dev. 2017, 42, 14-21. [CrossRef]

44. Calapre, L.; Warburton, L.; Millward, M.; Ziman, M.; Gray, E.S. Circulating Tumour DNA (CtDNA) as a Liquid Biopsy for Melanoma. Cancer Lett. 2017, 404, 62-69. [CrossRef] [PubMed]

45. Gray, E.S.; Rizos, H.; Reid, A.L.; Boyd, S.C.; Pereira, M.R.; Lo, J.; Tembe, V.; Freeman, J.; Lee, J.H.J.; Scolyer, R.A.; et al. Circulating Tumor DNA to Monitor Treatment Response and Detect Acquired Resistance in Patients with Metastatic Melanoma. Oncotarget 2015, 6, 42008-42018. [CrossRef] [PubMed]

46. Lipson, E.J.; Velculescu, V.E.; Pritchard, T.S.; Sausen, M.; Pardoll, D.M.; Topalian, S.L.; Diaz, L.A. Circulating Tumor DNA Analysis as a Real-Time Method for Monitoring Tumor Burden in Melanoma Patients Undergoing Treatment with Immune Checkpoint Blockade. J. Immunother. Cancer 2014, 2, 42. [CrossRef]

47. Hodis, E.; Watson, I.R.; Kryukov, G.V.; Arold, S.T.; Imielinski, M.; Theurillat, J.-P.; Nickerson, E.; Auclair, D.; Li, L.; Place, C.; et al. A Landscape of Driver Mutations in Melanoma. Cell 2012, 150, 251-263. [CrossRef]

48. Hodgson, D.R.; Wellings, R.; Orr, M.C.M.; McCormack, R.; Malone, M.; Board, R.E.; Cantarini, M.V. Circulating Tumour-Derived Predictive Biomarkers in Oncology. Drug Discov. Today 2010, 15, 98-101. [CrossRef] [PubMed]

49. Eslami-S, Z.; Cortés-Hernández, L.E.; Cayrefourcq, L.; Alix-Panabières, C. The Different Facets of Liquid Biopsy: A Kaleidoscopic View. Cold Spring Harb. Perspect. Med. 2020, 10, a037333. [CrossRef]

50. Sacco, A.; Forgione, L.; Carotenuto, M.; Luca, A.D.; Ascierto, P.A.; Botti, G.; Normanno, N. Circulating Tumor DNA Testing Opens New Perspectives in Melanoma Management. Cancers 2020, 12, 2914. [CrossRef]

51. Hood, J.L. Natural Melanoma-Derived Extracellular Vesicles. Semin. Cancer Biol. 2019, 59, 251-265. [CrossRef]

52. Hood, J.L.; Wickline, S.A. A Systematic Approach to Exosome-Based Translational Nanomedicine. Wiley Interdiscip. Rev. Nanomed. Nanobiotechnol. 2012, 4, 458-467. [CrossRef] [PubMed]

53. Kalluri, R. The Biology and Function of Exosomes in Cancer. J. Clin. Investig. 2016, 126, 1208-1215. [CrossRef]

54. Zhang, W.; Xia, W.; Lv, Z.; Ni, C.; Xin, Y.; Yang, L. Liquid Biopsy for Cancer: Circulating Tumor Cells, Circulating Free DNA or Exosomes? Cell. Physiol. Biochem. Int. J. Exp. Cell. Physiol. Biochem. Pharmacol. 2017, 41, 755-768. [CrossRef]

55. Rashed, M.H.; Bayraktar, E.; Helal, G.K.; Abd-Ellah, M.F.; Amero, P.; Chavez-Reyes, A.; Rodriguez-Aguayo, C. Exosomes: From Garbage Bins to Promising Therapeutic Targets. Int. J. Mol. Sci. 2017, 18, 538. [CrossRef] [PubMed]

56. Vlassov, A.V.; Magdaleno, S.; Setterquist, R.; Conrad, R. Exosomes: Current Knowledge of Their Composition, Biological Functions, and Diagnostic and Therapeutic Potentials. Biochim. Biophys. Acta 2012, 1820, 940-948. [CrossRef] [PubMed] 
57. Isola, A.L.; Eddy, K.; Chen, S. Biology, Therapy and Implications of Tumor Exosomes in the Progression of Melanoma. Cancers 2016, 8, 110. [CrossRef]

58. Lin, J.; Li, J.; Huang, B.; Liu, J.; Chen, X.; Chen, X.-M.; Xu, Y.-M.; Huang, L.-F.; Wang, X.-Z. Exosomes: Novel Biomarkers for Clinical Diagnosis. Sci. World J. 2015, 2015, 657086. [CrossRef]

59. Nedaeinia, R.; Manian, M.; Jazayeri, M.H.; Ranjbar, M.; Salehi, R.; Sharifi, M.; Mohaghegh, F.; Goli, M.; Jahednia, S.H.; Avan, A.; et al. Circulating Exosomes and Exosomal MicroRNAs as Biomarkers in Gastrointestinal Cancer. Cancer Gene Ther. 2017, 24, 48-56. [CrossRef] [PubMed]

60. Xiao, D.; Barry, S.; Kmetz, D.; Egger, M.; Pan, J.; Rai, S.N.; Qu, J.; McMasters, K.M.; Hao, H. Melanoma Cell-Derived Exosomes Promote Epithelial-Mesenchymal Transition in Primary Melanocytes through Paracrine/Autocrine Signaling in the Tumor Microenvironment. Cancer Lett. 2016, 376, 318-327. [CrossRef]

61. Xiao, D.; Ohlendorf, J.; Chen, Y.; Taylor, D.D.; Rai, S.N.; Waigel, S.; Zacharias, W.; Hao, H.; McMasters, K.M. Identifying MRNA, MicroRNA and Protein Profiles of Melanoma Exosomes. PLoS ONE 2012, 7, e46874. [CrossRef] [PubMed]

62. Peinado, H.; Alečković, M.; Lavotshkin, S.; Matei, I.; Costa-Silva, B.; Moreno-Bueno, G.; Hergueta-Redondo, M.; Williams, C.; García-Santos, G.; Ghajar, C.; et al. Melanoma Exosomes Educate Bone Marrow Progenitor Cells toward a Pro-Metastatic Phenotype through MET. Nat. Med. 2012, 18, 883-891. [CrossRef]

63. Namee, N.M.; O’Driscoll, L. Extracellular Vesicles and Anti-Cancer Drug Resistance. Biochim. Biophys. Acta Rev. Cancer 2018, 1870, 123-136. [CrossRef] [PubMed]

64. Cesi, G.; Philippidou, D.; Kozar, I.; Kim, Y.J.; Bernardin, F.; Van Niel, G.; Wienecke-Baldacchino, A.; Felten, P.; Letellier, E.; Dengler, S.; et al. A New ALK Isoform Transported by Extracellular Vesicles Confers Drug Resistance to Melanoma Cells. Mol. Cancer 2018, 17, 145. [CrossRef] [PubMed]

65. Vella, L.J.; Behren, A.; Coleman, B.; Greening, D.W.; Hill, A.F.; Cebon, J. Intercellular Resistance to BRAF Inhibition Can Be Mediated by Extracellular Vesicle-Associated PDGFR $\beta$. Neoplasia 2017, 19, 932-940. [CrossRef]

66. Eisenstein, A.; Gonzalez, E.C.; Raghunathan, R.; Xu, X.; Wu, M.; McLean, E.O.; McGee, J.; Ryu, B.; Alani, R.M. Emerging Biomarkers in Cutaneous Melanoma. Mol. Diagn. Ther. 2018, 22, 203-218. [CrossRef]

67. Joshi, P.; Jacobs, B.; Derakhshan, A.; Moore, L.R.; Elson, P.; Triozzi, P.L.; Borden, E.; Zborowski, M. Enrichment of Circulating Melanoma Cells (CMCs) Using Negative Selection from Patients with Metastatic Melanoma. Oncotarget 2014, 5, $2450-2461$. [CrossRef]

68. Rodic, S.; Mihalcioiu, C.; Saleh, R.R. Detection Methods of Circulating Tumor Cells in Cutaneous Melanoma: A Systematic Review. Crit. Rev. Oncol. Hematol. 2014, 91, 74-92. [CrossRef]

69. Aya-Bonilla, C.A.; Morici, M.; Hong, X.; McEvoy, A.C.; Sullivan, R.J.; Freeman, J.; Calapre, L.; Khattak, M.A.; Meniawy, T.; Millward, M.; et al. Detection and Prognostic Role of Heterogeneous Populations of Melanoma Circulating Tumour Cells. Br. J. Cancer 2020, 122, 1059-1067. [CrossRef] [PubMed]

70. Freeman, J.B.; Gray, E.S.; Millward, M.; Pearce, R.; Ziman, M. Evaluation of a Multi-Marker Immunomagnetic Enrichment Assay for the Quantification of Circulating Melanoma Cells. J. Transl. Med. 2012, 10, 192. [CrossRef]

71. Roland, C.L.; Ross, M.I.; Hall, C.S.; Laubacher, B.; Upshaw, J.; Anderson, A.E.; Lucci, A. Detection of Circulating Melanoma Cells in the Blood of Melanoma Patients: A Preliminary Study. Melanoma Res. 2015, 25, 335-341. [CrossRef] [PubMed]

72. Fusi, A.; Reichelt, U.; Busse, A.; Ochsenreither, S.; Rietz, A.; Maisel, M.; Keilholz, U. Expression of the Stem Cell Markers Nestin and CD133 on Circulating Melanoma Cells. J. Investig. Dermatol. 2011, 131, 487-494. [CrossRef]

73. Siewert, C.; Herber, M.; Hunzelmann, N.; Fodstad, O.; Miltenyi, S.; Assenmacher, M.; Schmitz, J. Rapid Enrichment and Detection of Melanoma Cells from Peripheral Blood Mononuclear Cells by a New Assay Combining Immunomagnetic Cell Sorting and Immunocytochemical Staining. Minimal Residual Dis. Melanoma 2001, 158, 51-60. [CrossRef]

74. Sakaizawa, K.; Goto, Y.; Kiniwa, Y.; Uchiyama, A.; Harada, K.; Shimada, S.; Saida, T.; Ferrone, S.; Takata, M.; Uhara, H.; et al. Mutation Analysis of BRAF and KIT in Circulating Melanoma Cells at the Single Cell Level. Br. J. Cancer 2012, 106, 939-946. [CrossRef]

75. Khoja, L.; Lorigan, P.; Zhou, C.; Lancashire, M.; Booth, J.; Cummings, J.; Califano, R.; Clack, G.; Hughes, A.; Dive, C. Biomarker Utility of Circulating Tumor Cells in Metastatic Cutaneous Melanoma. J. Investig. Dermatol. 2013, 133, 1582-1590. [CrossRef]

76. Rao, C.; Bui, T.; Connelly, M.; Doyle, G.; Karydis, I.; Middleton, M.R.; Clack, G.; Malone, M.; Coumans, F.A.W.; Terstappen, L.W.M.M. Circulating Melanoma Cells and Survival in Metastatic Melanoma. Int. J. Oncol. 2011, 38, 755-760. [CrossRef]

77. Halse, H.; Colebatch, A.J.; Petrone, P.; Henderson, M.A.; Mills, J.K.; Snow, H.; Westwood, J.A.; Sandhu, S.; Raleigh, J.M.; Behren, A.; et al. Multiplex Immunohistochemistry Accurately Defines the Immune Context of Metastatic Melanoma. Sci. Rep. 2018, 8, 11158. [CrossRef] [PubMed]

78. Goldschmidt, B.S.; Viator, J.A. Capture and Isolation of Circulating Melanoma Cells Using Photoacoustic Flowmetry. Methods Mol. Biol. Clifton NJ 2015, 1-9. [CrossRef]

79. Alix-Panabières, C. EPISPOT Assay: Detection of Viable DTCs/CTCs in Solid Tumor Patients. Recent Results Cancer Res. Fortschr. Krebsforsch. Progres Dans Rech. Sur Cancer 2012, 195, 69-76. [CrossRef]

80. Hasselmann, D.O.; Rappl, G.; Rössler, M.; Ugurel, S.; Tilgen, W.; Reinhold, U. Detection of Tumor-Associated Circulating MRNA in Serum, Plasma and Blood Cells from Patients with Disseminated Malignant Melanoma. Oncol. Rep. 2001, 8, 115-118. [CrossRef] 
81. Stevens, G.L.; Scheer, W.D.; Levine, E.A. Detection of Tyrosinase MRNA from the Blood of Melanoma Patients. Cancer Epidemiol. Biomark. 1996, 5, 293-296.

82. Smith, B.; Selby, P.; Southgate, J.; Pittman, K.; Bradley, C.; Blair, G.E. Detection of Melanoma Cells in Peripheral Blood by Means of Reverse Transcriptase and Polymerase Chain Reaction. Lancet Lond. Engl. 1991, 338, 1227-1229. [CrossRef]

83. Forthun, R.B.; Hovland, R.; Schuster, C.; Puntervoll, H.; Brodal, H.P.; Namløs, H.M.; Aasheim, L.B.; Meza-Zepeda, L.A.; Gjertsen, B.T.; Knappskog, S.; et al. CtDNA Detected by DdPCR Reveals Changes in Tumour Load in Metastatic Malignant Melanoma Treated with Bevacizumab. Sci. Rep. 2019, 9, 17471. [CrossRef] [PubMed]

84. Perkins, G.; Lu, H.; Garlan, F.; Taly, V. Droplet-Based Digital PCR: Application in Cancer Research. Adv. Clin. Chem. 2017, 79, 43-91. [CrossRef] [PubMed]

85. Shain, A.H.; Bastian, B.C. From Melanocytes to Melanomas. Nat. Rev. Cancer 2016, 16, 345-358. [CrossRef] [PubMed]

86. Hall, K.H.; Rapini, R.P. Acral Lentiginous Melanoma. In StatPearls; StatPearls Publishing: Treasure Island, FL, USA, 2021.

87. Postel, M.; Roosen, A.; Laurent-Puig, P.; Taly, V.; Wang-Renault, S.-F. Droplet-Based Digital PCR and next Generation Sequencing for Monitoring Circulating Tumor DNA: A Cancer Diagnostic Perspective. Expert Rev. Mol. Diagn. 2018, 18, 7-17. [CrossRef] [PubMed]

88. Knuever, J.; Weiss, J.; Persa, O.-D.; Kreuzer, K.; Mauch, C.; Hallek, M.; Schlaak, M. The Use of Circulating Cell-Free Tumor DNA in Routine Diagnostics of Metastatic Melanoma Patients. Sci. Rep. 2020, 10, 4940. [CrossRef]

89. Mosko, M.J.; Nakorchevsky, A.A.; Flores, E.; Metzler, H.; Ehrich, M.; van den Boom, D.J.; Sherwood, J.L.; Nygren, A.O.H. Ultrasensitive Detection of Multiplexed Somatic Mutations Using MALDI-TOF Mass Spectrometry. J. Mol. Diagn. JMD 2016, 18, 23-31. [CrossRef] [PubMed]

90. O'Leary, B.; Hrebien, S.; Beaney, M.; Fribbens, C.; Garcia-Murillas, I.; Jiang, J.; Li, Y.; Huang Bartlett, C.; André, F.; Loibl, S.; et al. Comparison of BEAMing and Droplet Digital PCR for Circulating Tumor DNA Analysis. Clin. Chem. 2019, 65, 1405-1413. [CrossRef] [PubMed]

91. Diefenbach, R.J.; Lee, J.H.; Rizos, H. Monitoring Melanoma Using Circulating Free DNA. Am. J. Clin. Dermatol. 2019, 20, 1-12. [CrossRef]

92. Wong, S.Q.; Raleigh, J.M.; Callahan, J.; Vergara, I.A.; Ftouni, S.; Hatzimihalis, A.; Colebatch, A.J.; Li, J.; Semple, T.; Doig, K.; et al. Circulating Tumor DNA Analysis and Functional Imaging Provide Complementary Approaches for Comprehensive Disease Monitoring in Metastatic Melanoma. JCO Precis. Oncol. 2017, 1-14. [CrossRef]

93. Váraljai, R.; Wistuba-Hamprecht, K.; Seremet, T.; Diaz, J.M.S.; Nsengimana, J.; Sucker, A.; Griewank, K.; Placke, J.-M.; Horn, P.A.; von Neuhoff, N.; et al. Application of Circulating Cell-Free Tumor DNA Profiles for Therapeutic Monitoring and Outcome Prediction in Genetically Heterogeneous Metastatic Melanoma. JCO Precis. Oncol. 2020, 3, PO.18.00229. [CrossRef] [PubMed]

94. McEvoy, A.C.; Calapre, L.; Pereira, M.R.; Giardina, T.; Robinson, C.; Khattak, M.A.; Meniawy, T.M.; Pritchard, A.L.; Hayward, N.K.; Amanuel, B.; et al. Sensitive Droplet Digital PCR Method for Detection of TERT Promoter Mutations in Cell Free DNA from Patients with Metastatic Melanoma. Oncotarget 2017, 8, 78890-78900. [CrossRef] [PubMed]

95. Chen, M.; Zhao, H. Next-Generation Sequencing in Liquid Biopsy: Cancer Screening and Early Detection. Hum. Genomics 2019, 13, 34. [CrossRef]

96. Diefenbach, R.J.; Lee, J.H.; Strbenac, D.; Yang, J.Y.H.; Menzies, A.M.; Carlino, M.S.; Long, G.V.; Spillane, A.J.; Stretch, J.R.; Saw, R.P.M.; et al. Analysis of the Whole-Exome Sequencing of Tumor and Circulating Tumor DNA in Metastatic Melanoma. Cancers 2019, 11, 1905. [CrossRef] [PubMed]

97. Imperial, R.; Nazer, M.; Ahmed, Z.; Kam, A.E.; Pluard, T.J.; Bahaj, W.; Levy, M.; Kuzel, T.M.; Hayden, D.M.; Pappas, S.G.; et al. Matched Whole-Genome Sequencing (WGS) and Whole-Exome Sequencing (WES) of Tumor Tissue with Circulating Tumor DNA (CtDNA) Analysis: Complementary Modalities in Clinical Practice. Cancers 2019, 11, 1399. [CrossRef]

98. Wee, E.J.H.; Wang, Y.; Tsao, S.C.-H.; Trau, M. Simple, Sensitive and Accurate Multiplex Detection of Clinically Important Melanoma DNA Mutations in Circulating Tumour DNA with SERS Nanotags. Theranostics 2016, 6, 1506-1513. [CrossRef]

99. Gorges, K.; Wiltfang, L.; Gorges, T.M.; Sartori, A.; Hildebrandt, L.; Keller, L.; Volkmer, B.; Peine, S.; Babayan, A.; Moll, I.; et al. Intra-Patient Heterogeneity of Circulating Tumor Cells and Circulating Tumor DNA in Blood of Melanoma Patients. Cancers 2019, 11, 1685. [CrossRef]

100. Salvianti, F.; Massi, D.; De Giorgi, V.; Gori, A.; Pazzagli, M.; Pinzani, P. Evaluation of the Liquid Biopsy for the Detection of BRAFV600E Mutation in Metastatic Melanoma Patients. Cancer Biomark. Sect. Dis. Markers 2019, 26, 271-279. [CrossRef]

101. Nanou, A.; Miller, M.C.; Zeune, L.L.; de Wit, S.; Punt, C.J.A.; Groen, H.J.M.; Hayes, D.F.; de Bono, J.S.; Terstappen, L.W.M.M. Tumour-Derived Extracellular Vesicles in Blood of Metastatic Cancer Patients Associate with Overall Survival. Br. J. Cancer 2020, 122, 801-811. [CrossRef]

102. Shu, S.L.; Yang, Y.; Allen, C.L.; Hurley, E.; Tung, K.H.; Minderman, H.; Wu, Y.; Ernstoff, M.S. Purity and Yield of Melanoma Exosomes Are Dependent on Isolation Method. J. Extracell. Vesicles 2020, 9, 1692401. [CrossRef] [PubMed]

103. Greening, D.W.; Xu, R.; Ji, H.; Tauro, B.J.; Simpson, R.J. A Protocol for Exosome Isolation and Characterization: Evaluation of Ultracentrifugation, Density-Gradient Separation, and Immunoaffinity Capture Methods. Methods Mol. Biol. Clifton NJ 2015, 1295, 179-209. [CrossRef] 
104. Théry, C.; Witwer, K.W.; Aikawa, E.; Alcaraz, M.J.; Anderson, J.D.; Andriantsitohaina, R.; Antoniou, A.; Arab, T.; Archer, F.; Atkin-Smith, G.K.; et al. Minimal Information for Studies of Extracellular Vesicles 2018 (MISEV2018): A Position Statement of the International Society for Extracellular Vesicles and Update of the MISEV2014 Guidelines. J. Extracell. Vesicles 2018, 7, 1535750. [CrossRef] [PubMed]

105. Sidhom, K.; Obi, P.O.; Saleem, A. A Review of Exosomal Isolation Methods: Is Size Exclusion Chromatography the Best Option? Int. J. Mol. Sci. 2020, 21, 6466. [CrossRef]

106. Böing, A.N.; van der Pol, E.; Grootemaat, A.E.; Coumans, F.A.W.; Sturk, A.; Nieuwland, R. Single-Step Isolation of Extracellular Vesicles by Size-Exclusion Chromatography. J. Extracell. Vesicles 2014, 3. [CrossRef]

107. Vergauwen, G.; Dhondt, B.; Van Deun, J.; De Smedt, E.; Berx, G.; Timmerman, E.; Gevaert, K.; Miinalainen, I.; Cocquyt, V.; Braems, G.; et al. Confounding Factors of Ultrafiltration and Protein Analysis in Extracellular Vesicle Research. Sci. Rep. 2017, 7, 2704. [CrossRef]

108. Kalluri, R.; LeBleu, V.S. The Biology, Function, and Biomedical Applications of Exosomes. Science 2020, 367, eaau6977. [CrossRef] [PubMed]

109. Kang, Y.-T.; Purcell, E.; Palacios-Rolston, C.; Lo, T.-W.; Ramnath, N.; Jolly, S.; Nagrath, S. Isolation and Profiling of Circulating Tumor-Associated Exosomes Using Extracellular Vesicular Lipid-Protein Binding Affinity Based Microfluidic Device. Small Weinh. Bergstr. Ger. 2019, 15, e1903600. [CrossRef]

110. Logozzi, M.; De Milito, A.; Lugini, L.; Borghi, M.; Calabrò, L.; Spada, M.; Perdicchio, M.; Marino, M.L.; Federici, C.; Iessi, E.; et al. High Levels of Exosomes Expressing CD63 and Caveolin-1 in Plasma of Melanoma Patients. PLoS ONE 2009, 4, e5219. [CrossRef]

111. Sharma, P.; Ludwig, S.; Muller, L.; Hong, C.S.; Kirkwood, J.M.; Ferrone, S.; Whiteside, T.L. Immunoaffinity-Based Isolation of Melanoma Cell-Derived Exosomes from Plasma of Patients with Melanoma. J. Extracell. Vesicles 2018, 7, 1435138. [CrossRef]

112. Ulmer, A.; Schmidt-Kittler, O.; Fischer, J.; Ellwanger, U.; Rassner, G.; Riethmüller, G.; Fierlbeck, G.; Klein, C.A. Immunomagnetic Enrichment, Genomic Characterization, and Prognostic Impact of Circulating Melanoma Cells. Clin. Cancer Res. Off. J. Am. Assoc. Cancer Res. 2004, 10, 531-537. [CrossRef]

113. Visús, C.; Andres, R.; Mayordomo, J.I.; Martinez-Lorenzo, M.J.; Murillo, L.; Sáez-Gutiérrez, B.; Diestre, C.; Marcos, I.; Astier, P.; Godino, J.; et al. Prognostic Role of Circulating Melanoma Cells Detected by Reverse Transcriptase-Polymerase Chain Reaction for Tyrosinase MRNA in Patients with Melanoma. Melanoma Res. 2007, 17, 83-89. [CrossRef]

114. Koyanagi, K.; Kuo, C.; Nakagawa, T.; Mori, T.; Ueno, H.; Lorico, A.R.; Wang, H.-J.; Hseuh, E.; O’Day, S.J.; Hoon, D.S.B. Multimarker Quantitative Real-Time PCR Detection of Circulating Melanoma Cells in Peripheral Blood: Relation to Disease Stage in Melanoma Patients. Clin. Chem. 2005, 51, 981-988. [CrossRef] [PubMed]

115. Garbe, C.; Leiter, U.; Ellwanger, U.; Blaheta, H.-J.; Meier, F.; Rassner, G.; Schittek, B. Diagnostic Value and Prognostic Significance of Protein S-100beta, Melanoma-Inhibitory Activity, and Tyrosinase/MART-1 Reverse Transcription-Polymerase Chain Reaction in the Follow-up of High-Risk Melanoma Patients. Cancer 2003, 97, 1737-1745. [CrossRef]

116. Brownbridge, G.G.; Gold, J.; Edward, M.; MacKie, R.M. Evaluation of the Use of Tyrosinase-Specific and MelanA/MART-1Specific Reverse Transcriptase-Coupled-Polymerase Chain Reaction to Detect Melanoma Cells in Peripheral Blood Samples from 299 Patients with Malignant Melanoma. Br. J. Dermatol. 2001, 144, 279-287. [CrossRef] [PubMed]

117. Khoja, L.; Lorigan, P.; Dive, C.; Keilholz, U.; Fusi, A. Circulating Tumour Cells as Tumour Biomarkers in Melanoma: Detection Methods and Clinical Relevance. Ann. Oncol. Off. J. Eur. Soc. Med. Oncol. 2015, 26, 33-39. [CrossRef] [PubMed]

118. Hoshimoto, S.; Faries, M.B.; Morton, D.L.; Shingai, T.; Kuo, C.; Wang, H.-J.; Elashoff, R.; Mozzillo, N.; Kelley, M.C.; Thompson, J.F.; et al. Assessment of Prognostic Circulating Tumor Cells in a Phase III Trial of Adjuvant Immunotherapy after Complete Resection of Stage IV Melanoma. Ann. Surg. 2012, 255, 357-362. [CrossRef] [PubMed]

119. Quaglino, P.; Osella-Abate, S.; Cappello, N.; Ortoncelli, M.; Nardò, T.; Fierro, M.T.; Cavallo, F.; Savoia, P.; Bernengo, M.G. Prognostic Relevance of Baseline and Sequential Peripheral Blood Tyrosinase Expression in 200 Consecutive Advanced Metastatic Melanoma Patients. Melanoma Res. 2007, 17, 75-82. [CrossRef] [PubMed]

120. Boldin, I.; Langmann, G.; Richtig, E.; Schwantzer, G.; Ardjomand, N.; Wegscheider, B.; El-Shabrawi, Y. Five-Year Results of Prognostic Value of Tyrosinase in Peripheral Blood of Uveal Melanoma Patients. Melanoma Res. 2005, 15, 503-507. [CrossRef]

121. Mazzini, C.; Pinzani, P.; Salvianti, F.; Scatena, C.; Paglierani, M.; Ucci, F.; Pazzagli, M.; Massi, D. Circulating Tumor Cells Detection and Counting in Uveal Melanomas by a Filtration-Based Method. Cancers 2014, 6, 323-332. [CrossRef]

122. Pinzani, P.; Mazzini, C.; Salvianti, F.; Massi, D.; Grifoni, R.; Paoletti, C.; Ucci, F.; Molinara, E.; Orlando, C.; Pazzagli, M.; et al. Tyrosinase MRNA Levels in the Blood of Uveal Melanoma Patients: Correlation with the Number of Circulating Tumor Cells and Tumor Progression. Melanoma Res. 2010, 20, 303-310. [CrossRef]

123. Schuster, R.; Bechrakis, N.E.; Stroux, A.; Busse, A.; Schmittel, A.; Thiel, E.; Foerster, M.H.; Keilholz, U. Prognostic Relevance of Circulating Tumor Cells in Metastatic Uveal Melanoma. Oncology 2011, 80, 57-62. [CrossRef] [PubMed]

124. Schuster, R.; Bechrakis, N.E.; Stroux, A.; Busse, A.; Schmittel, A.; Scheibenbogen, C.; Thiel, E.; Foerster, M.H.; Keilholz, U. Circulating Tumor Cells as Prognostic Factor for Distant Metastases and Survival in Patients with Primary Uveal Melanoma. Clin. Cancer Res. Off. J. Am. Assoc. Cancer Res. 2007, 13, 1171-1178. [CrossRef] [PubMed]

125. Mocellin, S.; Del Fiore, P.; Guarnieri, L.; Scalerta, R.; Foletto, M.; Chiarion, V.; Pilati, P.; Nitti, D.; Lise, M.; Rossi, C.R. Molecular Detection of Circulating Tumor Cells Is an Independent Prognostic Factor in Patients with High-Risk Cutaneous Melanoma. Int. J. Cancer 2004, 111, 741-745. [CrossRef] [PubMed] 
126. Gray, E.S.; Reid, A.L.; Bowyer, S.; Calapre, L.; Siew, K.; Pearce, R.; Cowell, L.; Frank, M.H.; Millward, M.; Ziman, M. Circulating Melanoma Cell Subpopulations: Their Heterogeneity and Differential Responses to Treatment. J. Investig. Dermatol. 2015, 135, 2040-2048. [CrossRef]

127. Kupas, V.; Weishaupt, C.; Siepmann, D.; Kaserer, M.-L.; Eickelmann, M.; Metze, D.; Luger, T.A.; Beissert, S.; Loser, K. RANK Is Expressed in Metastatic Melanoma and Highly Upregulated on Melanoma-Initiating Cells. J. Investig. Dermatol. 2011, 131, 944-955. [CrossRef]

128. Mocellin, S.; Hoon, D.; Ambrosi, A.; Nitti, D.; Rossi, C.R. The Prognostic Value of Circulating Tumor Cells in Patients with Melanoma: A Systematic Review and Meta-Analysis. Clin. Cancer Res. Off. J. Am. Assoc. Cancer Res. 2006, 12, 4605-4613. [CrossRef] [PubMed]

129. Luo, X.; Mitra, D.; Sullivan, R.J.; Wittner, B.S.; Kimura, A.M.; Pan, S.; Hoang, M.P.; Brannigan, B.W.; Lawrence, D.P.; Flaherty, K.T.; et al. Isolation and Molecular Characterization of Circulating Melanoma Cells. Cell Rep. 2014, 7, 645-653. [CrossRef]

130. Xu, X.; Zhong, J.F. Circulating Tumor Cells and Melanoma Progression. J. Investig. Dermatol. 2010, 130, 2349-2351. [CrossRef]

131. Spindler, K.-L.G.; Appelt, A.L.; Pallisgaard, N.; Andersen, R.F.; Brandslund, I.; Jakobsen, A. Cell-Free DNA in Healthy Individuals, Noncancerous Disease and Strong Prognostic Value in Colorectal Cancer. Int. J. Cancer 2014, 135, 2984-2991. [CrossRef]

132. Haselmann, V.; Gebhardt, C.; Brechtel, I.; Duda, A.; Czerwinski, C.; Sucker, A.; Holland-Letz, T.; Utikal, J.; Schadendorf, D.; Neumaier, M. Liquid Profiling of Circulating Tumor DNA in Plasma of Melanoma Patients for Companion Diagnostics and Monitoring of BRAF Inhibitor Therapy. Clin. Chem. 2018, 64, 830-842. [CrossRef]

133. Schreuer, M.; Meersseman, G.; Van Den Herrewegen, S.; Jansen, Y.; Chevolet, I.; Bott, A.; Wilgenhof, S.; Seremet, T.; Jacobs, B.; Buyl, R.; et al. Quantitative Assessment of BRAF V600 Mutant Circulating Cell-Free Tumor DNA as a Tool for Therapeutic Monitoring in Metastatic Melanoma Patients Treated with BRAF/MEK Inhibitors. J. Transl. Med. 2016, 14, 95. [CrossRef]

134. Sanmamed, M.F.; Fernández-Landázuri, S.; Rodríguez, C.; Zárate, R.; Lozano, M.D.; Zubiri, L.; Perez-Gracia, J.L.; Martín-Algarra, S.; González, A. Quantitative Cell-Free Circulating BRAFV600E Mutation Analysis by Use of Droplet Digital PCR in the Follow-up of Patients with Melanoma Being Treated with BRAF Inhibitors. Clin. Chem. 2015, 61, 297-304. [CrossRef] [PubMed]

135. Lee, J.H.; Menzies, A.M.; Carlino, M.S.; McEvoy, A.C.; Sandhu, S.; Weppler, A.M.; Diefenbach, R.J.; Dawson, S.-J.; Kefford, R.F.; Millward, M.J.; et al. Longitudinal Monitoring of CtDNA in Patients with Melanoma and Brain Metastases Treated with Immune Checkpoint Inhibitors. Clin. Cancer Res. Off. J. Am. Assoc. Cancer Res. 2020, 26, 4064-4071. [CrossRef] [PubMed]

136. Váraljai, R.; Elouali, S.; Lueong, S.S.; Wistuba-Hamprecht, K.; Seremet, T.; Siveke, J.T.; Becker, J.C.; Sucker, A.; Paschen, A.; Horn, P.A.; et al. The Predictive and Prognostic Significance of Cell-Free DNA Concentration in Melanoma. J. Eur. Acad. Dermatol. Venereol. JEADV 2021, 35, 387-395. [CrossRef] [PubMed]

137. Diefenbach, R.J.; Lee, J.H.; Rizos, H. Methylated Circulating Tumor DNA as a Biomarker in Cutaneous Melanoma. Melanoma Manag. 2020, 7, MMT46. [CrossRef]

138. Hoon, D.S.B.; Spugnardi, M.; Kuo, C.; Huang, S.K.; Morton, D.L.; Taback, B. Profiling Epigenetic Inactivation of Tumor Suppressor Genes in Tumors and Plasma from Cutaneous Melanoma Patients. Oncogene 2004, 23, 4014-4022. [CrossRef]

139. Marini, A.; Mirmohammadsadegh, A.; Nambiar, S.; Gustrau, A.; Ruzicka, T.; Hengge, U.R. Epigenetic Inactivation of Tumor Suppressor Genes in Serum of Patients with Cutaneous Melanoma. J. Investig. Dermatol. 2006, 126, 422-431. [CrossRef] [PubMed]

140. Salvianti, F.; Orlando, C.; Massi, D.; De Giorgi, V.; Grazzini, M.; Pazzagli, M.; Pinzani, P. Tumor-Related Methylated Cell-Free DNA and Circulating Tumor Cells in Melanoma. Front. Mol. Biosci. 2015, 2, 76. [CrossRef]

141. Mori, T.; O’Day, S.J.; Umetani, N.; Martinez, S.R.; Kitago, M.; Koyanagi, K.; Kuo, C.; Takeshima, T.-L.; Milford, R.; Wang, H.-J.; et al. Predictive Utility of Circulating Methylated DNA in Serum of Melanoma Patients Receiving Biochemotherapy. J. Clin. Oncol. Off. J. Am. Soc. Clin. Oncol. 2005, 23, 9351-9358. [CrossRef]

142. Koyanagi, K.; Mori, T.; O’Day, S.J.; Martinez, S.R.; Wang, H.-J.; Hoon, D.S.B. Association of Circulating Tumor Cells with Serum Tumor-Related Methylated DNA in Peripheral Blood of Melanoma Patients. Cancer Res. 2006, 66, 6111-6117. [CrossRef]

143. Hoshimoto, S.; Kuo, C.T.; Chong, K.K.; Takeshima, T.-L.; Takei, Y.; Li, M.W.; Huang, S.K.; Sim, M.-S.; Morton, D.L.; Hoon, D.S.B. AIM1 and LINE-1 Epigenetic Aberrations in Tumor and Serum Relate to Melanoma Progression and Disease Outcome. J. Investig. Dermatol. 2012, 132, 1689-1697. [CrossRef]

144. Sharma, P.; Diergaarde, B.; Ferrone, S.; Kirkwood, J.M.; Whiteside, T.L. Melanoma Cell-Derived Exosomes in Plasma of Melanoma Patients Suppress Functions of Immune Effector Cells. Sci. Rep. 2020, 10, 92. [CrossRef]

145. Cordonnier, M.; Nardin, C.; Chanteloup, G.; Derangere, V.; Algros, M.-P.; Arnould, L.; Garrido, C.; Aubin, F.; Gobbo, J. Tracking the Evolution of Circulating Exosomal-PD-L1 to Monitor Melanoma Patients. J. Extracell. Vesicles 2020, 9, 1710899. [CrossRef]

146. Alegre, E.; Zubiri, L.; Perez-Gracia, J.L.; González-Cao, M.; Soria, L.; Martín-Algarra, S.; González, A. Circulating Melanoma Exosomes as Diagnostic and Prognosis Biomarkers. Clin. Chim. Acta Int. J. Clin. Chem. 2016, 454, 28-32. [CrossRef]

147. Margue, C.; Reinsbach, S.; Philippidou, D.; Beaume, N.; Walters, C.; Schneider, J.G.; Nashan, D.; Behrmann, I.; Kreis, S. Comparison of a Healthy MiRNome with Melanoma Patient MiRNomes: Are MicroRNAs Suitable Serum Biomarkers for Cancer? Oncotarget 2015, 6, 12110-12127. [CrossRef]

148. Pfeffer, S.R.; Grossmann, K.F.; Cassidy, P.B.; Yang, C.H.; Fan, M.; Kopelovich, L.; Leachman, S.A.; Pfeffer, L.M. Detection of Exosomal MiRNAs in the Plasma of Melanoma Patients. J. Clin. Med. 2015, 4, 2012-2027. [CrossRef] 
149. Tengda, L.; Shuping, L.; Mingli, G.; Jie, G.; Yun, L.; Weiwei, Z.; Anmei, D. Serum Exosomal MicroRNAs as Potent Circulating Biomarkers for Melanoma. Melanoma Res. 2018, 28, 295-303. [CrossRef]

150. Alegre, E.; Sanmamed, M.F.; Rodriguez, C.; Carranza, O.; Martín-Algarra, S.; González, A. Study of Circulating MicroRNA-125b Levels in Serum Exosomes in Advanced Melanoma. Arch. Pathol. Lab. Med. 2014, 138, 828-832. [CrossRef] [PubMed]

151. Ragusa, M.; Barbagallo, C.; Statello, L.; Caltabiano, R.; Russo, A.; Puzzo, L.; Avitabile, T.; Longo, A.; Toro, M.D.; Barbagallo, D.; et al. MiRNA Profiling in Vitreous Humor, Vitreal Exosomes and Serum from Uveal Melanoma Patients: Pathological and Diagnostic Implications. Cancer Biol. Ther. 2015, 16, 1387-1396. [CrossRef] [PubMed]

152. García-Silva, S.; Benito-Martín, A.; Sánchez-Redondo, S.; Hernández-Barranco, A.; Ximénez-Embún, P.; Nogués, L.; Mazariegos, M.S.; Brinkmann, K.; Amor López, A.; Meyer, L.; et al. Use of Extracellular Vesicles from Lymphatic Drainage as Surrogate Markers of Melanoma Progression and BRAF V600E Mutation. J. Exp. Med. 2019, 216, 1061-1070. [CrossRef] [PubMed]

153. Klinac, D.; Gray, E.S.; Freeman, J.B.; Reid, A.; Bowyer, S.; Millward, M.; Ziman, M. Monitoring Changes in Circulating Tumour Cells as a Prognostic Indicator of Overall Survival and Treatment Response in Patients with Metastatic Melanoma. BMC Cancer 2014, 14, 423. [CrossRef]

154. Boyer, M.; Cayrefourcq, L.; Dereure, O.; Meunier, L.; Becquart, O.; Alix-Panabières, C. Clinical Relevance of Liquid Biopsy in Melanoma and Merkel Cell Carcinoma. Cancers 2020, 12, 960. [CrossRef]

155. Koyanagi, K.; O’Day, S.J.; Gonzalez, R.; Lewis, K.; Robinson, W.A.; Amatruda, T.T.; Wang, H.-J.; Elashoff, R.M.; Takeuchi, H.; Umetani, N.; et al. Serial Monitoring of Circulating Melanoma Cells during Neoadjuvant Biochemotherapy for Stage III Melanoma: Outcome Prediction in a Multicenter Trial. J. Clin. Oncol. Off. J. Am. Soc. Clin. Oncol. 2005, 23, 8057-8064. [CrossRef]

156. Reid, A.L.; Millward, M.; Pearce, R.; Lee, M.; Frank, M.H.; Ireland, A.; Monshizadeh, L.; Rai, T.; Heenan, P.; Medic, S.; et al. Markers of Circulating Tumour Cells in the Peripheral Blood of Patients with Melanoma Correlate with Disease Recurrence and Progression. Br. J. Dermatol. 2013, 168, 85-92. [CrossRef]

157. Khattak, M.A.; Reid, A.; Freeman, J.; Pereira, M.; McEvoy, A.; Lo, J.; Frank, M.H.; Meniawy, T.; Didan, A.; Spencer, I.; et al. PD-L1 Expression on Circulating Tumor Cells May Be Predictive of Response to Pembrolizumab in Advanced Melanoma: Results from a Pilot Study. The Oncologist 2020, 25, e520-e527. [CrossRef] [PubMed]

158. Girotti, M.R.; Gremel, G.; Lee, R.; Galvani, E.; Rothwell, D.; Viros, A.; Mandal, A.K.; Lim, K.H.J.; Saturno, G.; Furney, S.J.; et al. Application of Sequencing, Liquid Biopsies, and Patient-Derived Xenografts for Personalized Medicine in Melanoma. Cancer Discov. 2016, 6, 286-299. [CrossRef] [PubMed]

159. McEvoy, A.C.; Warburton, L.; Al-Ogaili, Z.; Celliers, L.; Calapre, L.; Pereira, M.R.; Khattak, M.A.; Meniawy, T.M.; Millward, M.; Ziman, M.; et al. Correlation between Circulating Tumour DNA and Metabolic Tumour Burden in Metastatic Melanoma Patients. BMC Cancer 2018, 18, 726. [CrossRef] [PubMed]

160. Braune, J.; Keller, L.; Schiller, F.; Graf, E.; Rafei-Shamsabadi, D.; Wehrle, J.; Follo, M.; Philipp, U.; Hussung, S.; Pfeifer, D.; et al. Circulating Tumor DNA Allows Early Treatment Monitoring in BRAF- and NRAS-Mutant Malignant Melanoma. JCO Precis. Oncol. 2020, 20-31. [CrossRef]

161. Long, G.V.; Fung, C.; Menzies, A.M.; Pupo, G.M.; Carlino, M.S.; Hyman, J.; Shahheydari, H.; Tembe, V.; Thompson, J.F.; Saw, R.P.; et al. Increased MAPK Reactivation in Early Resistance to Dabrafenib/Trametinib Combination Therapy of BRAFMutant Metastatic Melanoma. Nat. Commun. 2014, 5, 5694. [CrossRef] [PubMed]

162. Bettegowda, C.; Sausen, M.; Leary, R.J.; Kinde, I.; Wang, Y.; Agrawal, N.; Bartlett, B.R.; Wang, H.; Luber, B.; Alani, R.M.; et al. Detection of Circulating Tumor DNA in Early- and Late-Stage Human Malignancies. Sci. Transl. Med. 2014, 6, 224ra24. [CrossRef] [PubMed]

163. Ascierto, P.A.; Minor, D.; Ribas, A.; Lebbe, C.; O’Hagan, A.; Arya, N.; Guckert, M.; Schadendorf, D.; Kefford, R.F.; Grob, J.-J.; et al. Phase II Trial (BREAK-2) of the BRAF Inhibitor Dabrafenib (GSK2118436) in Patients with Metastatic Melanoma. J. Clin. Oncol. Off. J. Am. Soc. Clin. Oncol. 2013, 31, 3205-3211. [CrossRef] [PubMed]

164. Santiago-Walker, A.; Gagnon, R.; Mazumdar, J.; Casey, M.; Long, G.V.; Schadendorf, D.; Flaherty, K.; Kefford, R.; Hauschild, A.; $\mathrm{Hwu}$, P.; et al. Correlation of BRAF Mutation Status in Circulating-Free DNA and Tumor and Association with Clinical Outcome across Four BRAFi and MEKi Clinical Trials. Clin. Cancer Res. Off. J. Am. Assoc. Cancer Res. 2016, 22, 567-574. [CrossRef]

165. Valpione, S.; Gremel, G.; Mundra, P.; Middlehurst, P.; Galvani, E.; Girotti, M.R.; Lee, R.J.; Garner, G.; Dhomen, N.; Lorigan, P.C.; et al. Plasma Total Cell-Free DNA (CfDNA) Is a Surrogate Biomarker for Tumour Burden and a Prognostic Biomarker for Survival in Metastatic Melanoma Patients. Eur. J. Cancer Oxf. Engl. 2018, 88, 1-9. [CrossRef] [PubMed]

166. Lee, J.H.; Long, G.V.; Boyd, S.; Lo, S.; Menzies, A.M.; Tembe, V.; Guminski, A.; Jakrot, V.; Scolyer, R.A.; Mann, G.J.; et al. Circulating Tumour DNA Predicts Response to Anti-PD1 Antibodies in Metastatic Melanoma. Ann. Oncol. Off. J. Eur. Soc. Med. Oncol. 2017, 28, 1130-1136. [CrossRef] [PubMed]

167. Seremet, T.; Jansen, Y.; Planken, S.; Njimi, H.; Delaunoy, M.; El Housni, H.; Awada, G.; Schwarze, J.K.; Keyaerts, M.; Everaert, H.; et al. Undetectable Circulating Tumor DNA (CtDNA) Levels Correlate with Favorable Outcome in Metastatic Melanoma Patients Treated with Anti-PD1 Therapy. J. Transl. Med. 2019, 17, 303. [CrossRef]

168. Lee, J.H.; Long, G.V.; Menzies, A.M.; Lo, S.; Guminski, A.; Whitbourne, K.; Peranec, M.; Scolyer, R.; Kefford, R.F.; Rizos, H.; et al. Association Between Circulating Tumor DNA and Pseudoprogression in Patients With Metastatic Melanoma Treated With Anti-Programmed Cell Death 1 Antibodies. JAMA Oncol. 2018, 4, 717-721. [CrossRef] [PubMed]

169. Chang, G.A.; Tadepalli, J.S.; Shao, Y.; Zhang, Y.; Weiss, S.; Robinson, E.; Spittle, C.; Furtado, M.; Shelton, D.N.; Karlin-Neumann, G.; et al. Sensitivity of Plasma BRAFmutant and NRASmutant Cell-Free DNA Assays to Detect Metastatic 
Melanoma in Patients with Low RECIST Scores and Non-RECIST Disease Progression. Mol. Oncol. 2016, 10, 157-165. [CrossRef] [PubMed]

170. Chen, G.; Huang, A.C.; Zhang, W.; Zhang, G.; Wu, M.; Xu, W.; Yu, Z.; Yang, J.; Wang, B.; Sun, H.; et al. Exosomal PD-L1 Contributes to Immunosuppression and Is Associated with Anti-PD-1 Response. Nature 2018, 560, 382-386. [CrossRef]

171. Del Re, M.; Marconcini, R.; Pasquini, G.; Rofi, E.; Vivaldi, C.; Bloise, F.; Restante, G.; Arrigoni, E.; Caparello, C.; Bianco, M.G.; et al. PD-L1 MRNA Expression in Plasma-Derived Exosomes Is Associated with Response to Anti-PD-1 Antibodies in Melanoma and NSCLC. Br. J. Cancer 2018, 118, 820-824. [CrossRef]

172. Tucci, M.; Passarelli, A.; Mannavola, F.; Stucci, L.S.; Ascierto, P.A.; Capone, M.; Madonna, G.; Lopalco, P.; Silvestris, F. Serum Exosomes as Predictors of Clinical Response to Ipilimumab in Metastatic Melanoma. Oncoimmunology 2018, 7, e1387706. [CrossRef]

173. Svedman, F.C.; Lohcharoenkal, W.; Bottai, M.; Brage, S.E.; Sonkoly, E.; Hansson, J.; Pivarcsi, A.; Eriksson, H. Extracellular Microvesicle MicroRNAs as Predictive Biomarkers for Targeted Therapy in Metastastic Cutaneous Malignant Melanoma. PLoS ONE 2018, 13, e0206942. [CrossRef] [PubMed]

174. Lunavat, T.R.; Cheng, L.; Einarsdottir, B.O.; Olofsson Bagge, R.; Veppil Muralidharan, S.; Sharples, R.A.; Lässer, C.; Gho, Y.S.; Hill, A.F.; Nilsson, J.A.; et al. BRAFV600 Inhibition Alters the MicroRNA Cargo in the Vesicular Secretome of Malignant Melanoma Cells. Proc. Natl. Acad. Sci. USA 2017, 114, E5930-E5939. [CrossRef] [PubMed]

175. Home-ClinicalTrials.Gov. Available online: https:/ / clinicaltrials.gov/ (accessed on 6 July 2021).

176. Lianidou, E.S.; Markou, A.; Strati, A. The Role of CTCs as Tumor Biomarkers. Adv. Exp. Med. Biol. 2015, 867, 341-367. [CrossRef]

177. Batth, I.S.; Mitra, A.; Manier, S.; Ghobrial, I.M.; Menter, D.; Kopetz, S.; Li, S. Circulating Tumor Markers: Harmonizing the Yin and Yang of CTCs and CtDNA for Precision Medicine. Ann. Oncol. Off. J. Eur. Soc. Med. Oncol. 2017, 28, 468-477. [CrossRef] [PubMed]

178. Xiong, T.-F.; Pan, F.-Q.; Li, D. Expression and Clinical Significance of S100 Family Genes in Patients with Melanoma. Melanoma Res. 2019, 29, 23-29. [CrossRef] 